Article

\title{
City-as-a-Platform: The Rise of Participatory Innovation Platforms in Finnish Cities
}

\author{
Ari-Veikko Anttiroiko
}

School of Management, University of Tampere, Tampere 33014, Finland; kuaran@uta.fi; Tel.: +358-040-1904017

Academic Editor: Nicos Komninos

Received: 5 July 2016; Accepted: 5 September 2016; Published: 10 September 2016

\begin{abstract}
This article discusses the idea of city as a platform. The analysis focuses on the forms and implications of citizen involvement in publicly-supported participatory innovation platforms that facilitate urban economic development in the welfare society context. The discussion opens with a review of the smart city discourse, which in the context of economic development policy translates into cities' need to support innovativeness by creating smart environments. Participatory innovation platform is a prime example of such an environment. The empirical section discusses three cases, those of the Finnish cities of Helsinki, Tampere, and Oulu. The analysis shows that platformization in the first half of the 2010s became a strategic focal area supported by national and EU programs. Platforms are used to support both urban revitalization and economic development, of which the former is based on representative and the latter on instrumental modes of participation. Platforms are well integrated with city governments, even though they vary greatly in terms of organizational forms and scopes. Democratic culture, welfarism, and redistributive policy provide contextual support for platformization by strengthening social inclusion, taming the growth machine, and easing the tensions between pro-growth and anti-growth coalitions.
\end{abstract}

Keywords: smart city; urban development; local economic development; city; citizen; participation; innovation; platform; platformization; Finland

\section{Introduction}

Globalization in urban life manifests in various ways, one of them being global competition between cities for investments, talent, and tourists. Such competition started to intensify in the late 1940s due to the liberalization of world trade. A few decades later, its impact on economic geography came to be dramatically felt in most of the industrialized cities in the Western world, as they started to lose their manufacturing jobs as companies-in the name of competitiveness and profit maximization-relocated their production to low-cost countries. During the following decades the organizational decomposition of production and innovation processes together with such accompanying trends as servitization, digitalization, creativization, and financialization of the economy drastically altered the appearance of the global economy [1-4].

At the local level rapid changes in the economic system and the intensification of global competition begot a challenge revolving around urban economic renewal. As innovation appeared to be critical for economic development, city governments' comprehensible response was to devote attention to both the innovation capability of local firms and urban innovation milieus, both supporting local firms and attracting business and talent from elsewhere.

Even if it is compulsory to consider firms' immediate innovation needs, complex economic reality compels us to take a broader, contextual view of the promotion of innovativeness. There are several indicators of current economic development that point in this direction, of which two are of particular relevance for our discussion. First, users and communities have become an integral part of global innovation ecology due to the gradual opening up of firms' innovation processes and the 
new role of lead users and enthusiasts, which is referred to as the democratization of innovation [5-9]. Another important factor is increased interdependence in the global economy. One of its manifestations is platformization, which describes the emergence of platforms and their development towards interconnected ecosystems as a new precondition for business development and growth $[10,11]$. Conventional pipeline firms have difficulties surviving in this environment in which product and industry platforms and related ecosystems are gaining ground. In platform business companies must pay special attention to three key issues: orchestrating resources, facilitating interaction, and focusing on ecosystem value [12]. Even if the identification of this trend is largely based on observations on successful information technology, Internet, software, e-commerce and social media companies-most notably Apple, Google, Microsoft, Oracle, Amazon, eBay and Facebook-and can thus be seen as an exaggerated story derived from experiences in high-tech industries or business that grew at the time of the proliferation of the Internet, platformization has also be seen as a prelude to a pervasive platform revolution, which is a continuation of digital revolution.

Democratization of innovation and platformization in business have their counterpart in the lives of territorial communities. City governments need to support local business development as successful companies create jobs and form a basis for local prosperity. Local economic development policy is increasingly fused with technology and innovation policies, which is apparent in cities' general interest in developing innovation environments of various scales, ranging from larger innovation districts to small-scale incubators and other micro environments. The emergence of innovation labs in public-sector organizations, living labs and the government-sponsored participatory innovation platforms is part of the same trend. We may hypothesize that open innovation and user-centered design in business may actually be mutually reinforcing with the participatory turn in the public sector [13,14], provided that societal and cultural conditions support such integration. This view points to a kind of institutional counterpart to von Hippel's idea of the democratization of innovation, in which lead users, with the help of new technologies, develop their own new products and services, share them with others, and create rich intellectual commons [6,15]. While von Hippel discusses people's self-organized actions, our discussion involves government intervention motivated by a generic goal of local economic development.

This picture is not complete without citizens or local residents, who are supposed to participate in innovation processes through platforms. Who are these citizens and what makes them so important? Citizens refer to all residents of a city, both permanent and temporary. Citizens have different roles in public life, including those of political actor, resident, worker, service user, activist, and so forth, and practically all of them can potentially be seen in participatory innovation platforms, depending on what kind of innovations are sought in each case. For example, the platform may seek urban innovations in order to promote neighborhood revitalization; service innovations to improve public services; or product innovations to help local firms to succeed. The benefits of citizen participation are manifold, including contributions to ideation, understanding of users and the contexts of use, prototype and usability testing, and co-design [8]. If the open platform practices are extended to the city level, the user perspective begins to become blurred with resident, community member and political roles, and consequently the city itself starts to look like an extended platform or living lab [16].

The comprehensive understanding of the nature of participatory innovation platforms requires that they are put in an institutional and societal context. The former focuses on institutional design and practices - the essence of such analysis being in how institutions affect human behavior-whereas the latter approach supplements it with the view that political, economic, and socio-cultural contexts condition in many ways the design and functioning of local institutions as they do with human behavior in general. This article focuses on the particular societal context characterized by welfarism, post-industrialism, and democracy, of which Finland and other Nordic countries are good examples. Platformization can be seen as process reflecting the interplay of democratic culture and economic development. Their relationship can theoretically be seen as either completely separated or fully 
integrated, or antagonistic vs. mutually supportive, which determines whether the approach to innovation platform design and management is producer-centered or society-centered.

This discussion has its original motivation in the restructuring challenge faced by democratically governed welfare societies that have reached a post-industrial stage of economic development. How do such conditions, and especially the underlying democratic culture, affect the preconditions for developing business-citizen interfaces and innovation platforms? The hypothesis is that democratic culture and governance practices, when properly molded and facilitated, can promote the utilization of innovation potential thereby improving the conditions and capabilities of local business. Academic research on this topic can help not only to critically assess the preconditions for business-citizen interaction and especially the roles assigned to citizens in innovation processes, but also to better understand the conditions for the utilization of democratic culture in building and managing platforms that facilitate such interaction.

To sum up, this article seeks answer to the following research question: What are the forms and implications of citizen involvement in publicly-supported participatory innovation platforms that facilitate urban economic development in the welfare society context? The discussion focuses on the following three questions:

(i) What is the strategic orientation of cities towards platformization in local economic development in the given societal context?

(ii) What is the role of participatory innovation platforms in connecting democratic participation with business development and what are the forms of citizen participation in such platforms?

(iii) What are the social implications of the use of participatory innovation platforms in business-citizen interaction?

The research strategy applied is case study [17]. The cases revolve around the participatory innovation platforms of the cities of Helsinki, Tampere, and Oulu in Finland. Data collection and analysis are described in more detail in the methodology section.

\section{Methodology}

Methodologically, this is a theoretically-oriented case analysis of three leading Finnish post-industrial cities and their national context. Case study research focuses on a phenomenon in a real-life setting [17]. We focus on the cities of Helsinki, Tampere and Oulu, which represent cities in different parts of the country with an explicit commitment to the smart city agenda in their economic development policies. They all have established various innovation platforms, and, more importantly, exemplify the participatory turn in the rationale of such platformization.

The empirical data sources utilized in this study comprise written documents, interviews and personal communications. Concerning the first category, policy documents and media sources of strategic relevance are reviewed to provide an accurate picture of the strategic approach to platform design in three Finnish cities. Three strategy documents were reviewed: Helsinki Strategy Program of 2013-2016, Tampere: Working Together for a Bright Future-Tampere City Strategy 2025, and City Strategy Oulu 2020 [18-20]. In addition, the innovation strategy for the Helsinki region was reviewed as it has a special relevance for the case of Helsinki [21], as is also a Six City Strategy (6Aika), which guides the collaboration between the six largest cities in Finland [22]. Besides primary sources, in the descriptions of three cities secondary sources are also utilized, which helps in providing an accurate picture of local contexts and of the forms and activities of innovation platforms.

Additional empirical data were collected in August 2016 through interviews, e-interviews, and personal communications (note: as some informants answered the interview questions on the basis of an e-mail message forwarded by the recipient of the original e-mail interview request, such e-mails are treated here as personal communications). Informants were mainly development and project managers involved in local economic development, development projects and innovation platforms in the three Finnish cities, being people with first-hand experience of the launch and early-stage development 
of participatory platforms. There were in all three informants from Helsinki, six from Tampere, and four from Oulu. Details of official positions and the dates of interviews and personal communications are included in the reference list. As this research is exploratory and deals primarily with the problem of ambiguity rather than uncertainty, following Daft and Lengel's [23] terminology, interviews and personal communications included a few thematically focused open-ended questions intended to elicit the key informants' understanding and experiences of the local instances of business-citizen interaction in the context of innovation-driven local economic development policy.

On the basis of qualitative assessment of empirical data and descriptive institutional analysis, the discussion continues with a critical contextual interpretation of participatory innovation platforms. The discussion is framed with a theorization of urban economic development with three major layers of analysis: the smart city discourse providing a view of the idea of smartness in the development of urban communities, platform theory depicting the forms and functioning of micro environments designed for user, customer, and resident involvement in innovation processes, and the theory of participation offering a critical view of the forms and functions of citizen involvement in facilitated development and innovation processes.

The contextual view of participation in innovation platforms goes beyond the factual participatory processes by conceiving of such processes in their historical, cultural, and societal settings, which in this case refers primarily to the role of political and administrative institutions in a broadly defined economy and the critical assessment of the outcomes of their interplay. In this sense, the analysis is loosely connected to sociological institutionalism and political economy analysis $[24,25]$. The methodological scheme of this research is illustrated in Figure 1.

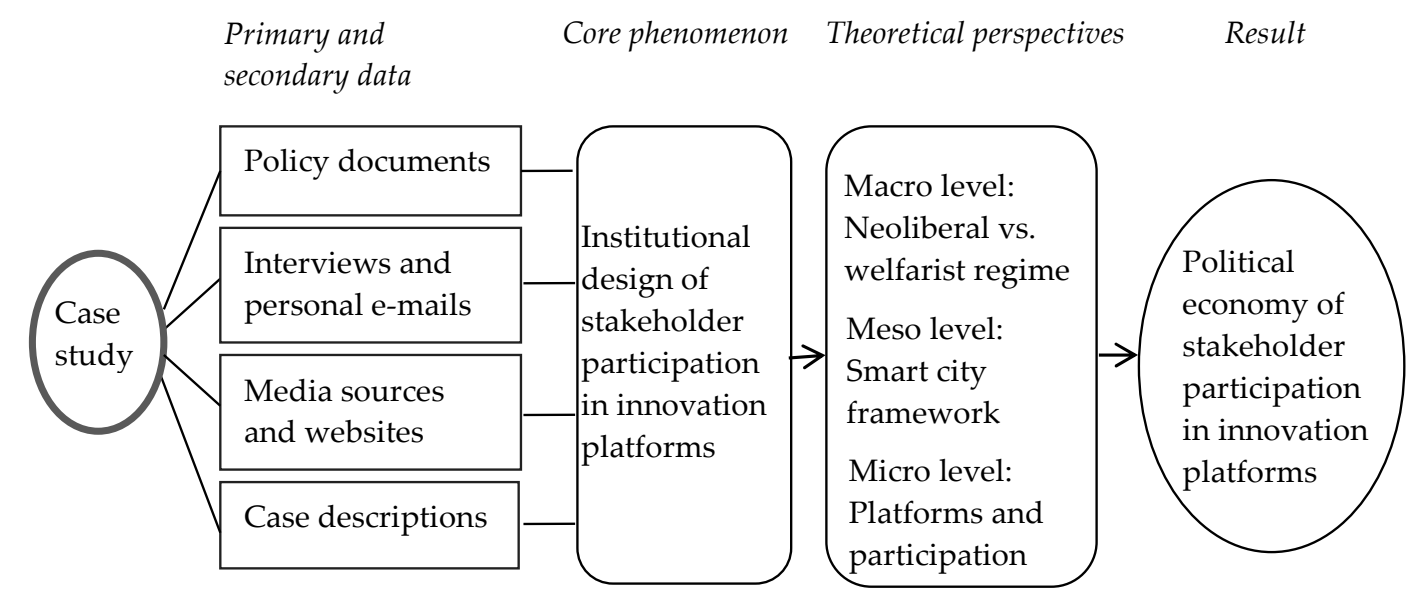

Figure 1. Methodological scheme of the research.

\section{Theoretical Framework}

\subsection{A Smart City Framework for Urban Development}

The smart city discourse has many strands. Since the late 1990s the key issue has been digitalization, even if this continuously evolving discourse has taken up numerous other relevant dimensions of smartness in urban life [26-34]. The following six dimensions, sometimes referred to as the Smart City Wheel [35], have been mentioned as key application fields: people, environment, economy, governance, mobility, and living [32,36]. Even if the original idea of smart city is rooted in technological advancements as the principal enabling factor, the recent literature repeatedly emphasizes the need to put smartness in a broader context. In short, new technologies do not form a sufficient condition for the creation of a smart city. Battarra and others [37], for example, emphasize that a smart city is made of smart people who are supposed to create and benefit from the smart city development model through synergies made possible by governance structures and smart institutions [38]. In this 
complex environment there is need for an integrated approach, which emphasizes the role of citizens as informed, networked, and empowered co-creators of the smart city, including their role in helping business to become more innovative, productive and agile [33]. To summarize, smart city refers to a multi-dimensional urban development model, in which technological advancements are used to enhance collective intelligence and systemic capabilities aiming to enhance competitiveness, effectiveness, quality of life, and sustainability in the urban community $[29,37,39,40]$.

The dynamics of smart city revolve around the technologically enhanced ability to transform our environment and social practices in order to produce public value. A particular aspect of urban life that creates a precondition for such smartness is public access to government information and the ability to reuse and redistribute it, usually referred to as open data. Murgante and Borruso [41] have seen data and open data in particular as one of the pillars of a smart city, for they have potential to take social interaction to a new level and facilitate the development of innovative solutions from business to public governance. Often such data also include some reference to location, which connect them with urban life. Interestingly, data are "raw value" at the intersection of the public and private realms, for they are a vital resource in democratic governance as well as a source of significant economic potential. In other words, availability and transparency of data forms a pool that feeds the collective imagination and can be transformed by business, institutional and civic entrepreneurs into new service concepts, product innovations, and business models. Availability and reusability of data is also a building block in the Big Data trend, in which knowledge-processing actors, through data mining, analytics, and synthesis produce from the diversity of data sources contextually meaningful information applicable to such purposes as smart resourcing, operational solutions, and knowledge-based value creation [42].

Another dimension of smartness is an outcome of systemic and collective intelligence. The human or rather social side of such intelligence assumes that a heterogeneous group of people is generally able to provide smarter solutions than an individual expert, i.e., diversity trumps expertise $[43,44]$. This connects the smart city discourse to inclusive, open and user-driven innovations as critical elements of smart urban development $[45,46]$. It resembles the idea of adding citizens and users to the institutional triangle of government, business, and academia, referred to as the Quadruple Helix [47]. In recent discourse, such a dimension has been radicalized by associating smartness with a kind of social intelligence at the intersection of physical space, digital technologies, and mediated forms of sharing, thus creating an important connection with justice, solidarity, and sustainability [48]. Concerning the last point, in the wake of global environmental concern sustainable development has become an integral part of the smart city agenda [32,33,49,50].

In the economic context, smartness can be associated with such firm-level qualities as innovativeness, productivity, business intelligence, transformative capacity, and resilience. Taken to the community-level, a range of institutional and structural aspects of urban development come under the spotlight, including flexibility of labor markets, the facilitation capacity of the institutional environment, and urban-regional governance capacity and leadership [51]. The smart city framework urges city governments to develop strategies that guide the utilization of internet infrastructures, living labs, testbed facilities and open innovation forums in an inclusive manner [52]. The idea is to stimulate experimentation, innovation, and commercialization by bringing users and developers into the same micro-environments and empowering user communities, which eventually form an integral part of the urban innovation ecosystem. In the urban context, such technological opportunities must be assessed against the economic, social, and environmental objectives of the city [53]. In this article, the focus is on innovativeness, as it is one of the critical factors of urban economic development and forms an activity area in which user, customer, stakeholder, and citizen involvement has increased considerably within the last ten years.

\subsection{Smartness through Platformization}

Smart city concept provides a framework for understanding the opportunities of technological advancements for urban development. As a multi-faceted and vague concept it has its limits, however. 
Besides, in spite of all the discussion during the few last years, at a practical level, it is still affected by technological determinism and a kind of "infrastructure engineering" approach, which associates smart city with smart systems and structures, such as intelligent transport systems and energy-efficient buildings. This is particularly problematic if we wish to understand such a complex entity as city. Platform has emerged as a metaphor and a vision that provides an inspiring view of what smart city could be like if it is built on citizens and their social relations. Such a concept is sometimes referred to as City-as-a-Platform (CaaP).

The story starts from the computerization of cities in the 1960s and 1970s. It focused on the utilization of ICTs in existing administrative functions and workflow processes. A critical juncture was the Great Internet Explosion in the first half of the 1990s, which dramatically transformed the technological landscape. Consequently, cities started to investigate their chances to better utilize existing digital data in interaction with citizens and other stakeholders. As most of the IT development took place separately in each city, computer systems did not communicate with each other particularly well. They were islands of software even within a single city; central administration, police, hospital, and other institutions had their own systems. Platformization offers a vision of the full interoperability of interrelated information systems. Platforms are thus supposed to support and interconnect practically all the digital functionality the city needs to serve its internal and external audiences [54]. We have already seen how digitalization changes our everyday lives. People live their lives in various kinds of hyper-connected virtual spaces, abounding in real-time information, intelligent devices, remote-access databases, and crowdsourcing [10]. This is a first step to understanding the emergence of a platform city.

Platform city has its digital foundations, a layer that combines the IT ecosystem with data. It is needed to build sustainable solutions from the data we collectively produce. This is ultimately about our relationship with technology: How does "digital" change our engagement with our city? This implies a new relationship between citizens, the city government, and the surrounding urban community, and open data are a critical nexus in this picture. As Grech puts it, "All of us need to recognize that putting our data to use in a meaningful way can improve our lives. But city officials have a part to play. They must create the appropriate systems and publicly accountable spaces to ensure measurable and effective use of data" [55].

Platformization integrates the data issue with public policy and governance. Using the phrase coined by Steve Adler, we may say that we are witnessing a transition "from public policy to public engagement". The idea is that the city government is on its way to change from a bureaucratic mechanism organized into silos to solve collective problems to a platform where people gather to communicate and share ideas, utilize open data and other resources, and co-create solutions to both utilize development opportunities and solve perceived problems [56]. Thus, City-as-a-Platform conveys a radical message of the need to move away from the centralized command-and-control models of governance and the superiority of professionals and experts to a model that invites decentralized participation and innovation by citizens via networks. In practical terms, such platform governance means open data systems, push notifications to citizens and crowdsourcing of information to improve the services and management of the city, the underlying radical idea being to foster shifts of power, wealth, and voice in the life of the city [10].

Platform thinking creates intersections between local policy-making, urban activism and digital living. For example, Reykjavik, the capital of Iceland, opened datasets and worked with civil society activists to create a platform so that the public could propose and prioritize new ideas for the city. The Market Street Prototyping Festival in San Francisco, organized collaboratively by the San Francisco Planning Department and the Yerba Buena Center for the Arts, is an endeavor to design a vibrant and connected street that reflects the ideas and aspirations of local people. Tel Aviv launched a DigiTel Resident Card for personalized information, rates, and discounts and live updates on everything the city has to offer based on personal interests and inquiries. It aims to take the interaction between citizens and the city government to a new level. There are many similar examples of digital and 
smart city initiatives around the world, which lead us towards platform city. The development has its prerequisites. Most notably, an empowered disrupted democratic approach becomes possible only if there is sufficient political will and a culture of citizen empowerment and co-creation [55].

\subsection{Platform Functions in Innovation Process}

In general, platform is any physical, technological or social base on which economic and socio-technical processes are built $[45,57,58]$. Historically, platforms were essentially physical sites, yet due to technological development they have become increasingly digital, dispersed and delocalized [51]. From a business point of view, the rationale behind the creation of such platforms is that innovation-driven competition takes place in an increasingly interconnected world, which implies that collaboration and networking are an important source of competitive advantage. They have started to open their innovation practices by adopting the open innovation paradigm and allowing actors from outside to engage in the innovation networks and platforms they are involved in [59]. Moreover, the hectic development, especially in rapidly changing high-tech industries, has made platforms into critical elements in both business strategy and market condition. The point is that, unlike in product-oriented approach, platform economy emphasizes the role of the external ecosystem, which generates and utilizes complementary product or service innovations. If a platform leader collaborates successfully with other companies, they may together create an innovation ecosystem that increases the value of their innovations and create synergies and network effects that improve their competitive advantage, as has been the case with such companies as Microsoft, Apple and Google [60]. This highlights the need to understand the increasingly extra-local and relational nature of platforms, which also indirectly affect government-sponsored platformization.

Platforms facilitate people's value creation by providing some methods relevant for the interconnected actions that work through the critical mass of users and their inputs. They provide a structured and enabling environment for technologies, applications or social processes with a potential of smartening up their development $([45,57,61,62])$. What is essential in platforms, and participatory platforms in particular, is their ability to replace hierarchical structures as a means of control, which is important if such a platform is supposed to be inclusive and support creativity [63] (pp. 3 and 7), [33]. Platformization has many manifestations in the public realm, starting from institutionalized urban planning procedures and internally-oriented innovation labs [64]. Besides these, there are local innovation incubators, accelerators, and programs [65], regular events (e.g., Slush in Helsinki), business-driven platforms [66,67], virtual communities and new community networks, as well as Web 2.0 style forums and creative ad hoc communities [45]. Our interest is in participatory innovation platforms which match business with citizens with the purpose of supporting innovation-driven urban economic development.

Such innovation platforms primarily perform four major functions: (i) providing open access and encouraging broad-based stakeholder involvement; (ii) enhancing individual, group, and community creativity; (iii) facilitating open dialogue and sharing; and (iv) supporting convergent thinking, decision-making and policy integration [33,63,68-71]. Through such functions platforms bring added value to local knowledge processes, which are critical to the innovativeness and smartness of local economic development. These functions match roughly with the phases of innovation management process, which involve several steps from idea generation and concept development to implementation [72-74].

Whether government should intervene in platform formation is debatable. Some academics argue that a government's support for and active involvement in innovation platforms with several independent participants may be in the public interest, as long as the participants have sufficient common interest in the planned innovation, there is sufficient trust between them, and the required human and financial resources are available for joint learning and development. In addition, attention should be paid to concrete objectives and outputs, such as inventions and their commercialization, in order to be able to work in a focused manner and measure the results [75]. 


\subsection{Theorizing Citizen Involvement in Local Platforms}

The development of media and new technologies has contributed significantly to the increase in complexity in business, governance, and social life. It has brought about new local information networks as a part of communicative ecology, and these have a critical facilitative role in determining the direction for urban transformation. An early indication of this trend was the increased relevance of user-generated content in social media, which, together with new forms of e-participation and co-creation and the impact of ubiquitous connectivity and other trends that changed the real-virtual interface, have transformed the urban communicative landscape and the precondition for urban informatics [76,77]. What emanates from this is a collective intelligence, be it aggregation of opinions or the wisdom of crowds [78]. In order for such practices to develop in a balanced and responsible way, there is a need for a participatory culture that supports, guides and controls such development [77]. This perspective leads to the emphasis of the relevance of diversity and creativity.

The utilization of diversity and creativity requires open participation at community level. The people who are supposed to participate are generally called "citizens", even if the concept of citizen also carries strict political and judicial meanings. Citizens' paradigmatic roles in urban economic development may be of two kinds: (i) a political actor, community member or a resident who participates in democratically organized policy making, planning or governance process; or (ii) a consumer, customer or user who participates in a facilitated user-driven innovation process. The latter may include various segments, such as students, senior citizens or families with children. In the very pragmatic sense being a "citizen" in this context thus implies voluntary involvement either as a member of the community or a resident or alternatively as a representative of a customer or user group. For this reason, if some specific stakeholder groups with particular institutional affiliation, such as university faculty members, public sector employees or business managers, are involved in an innovation process, they are treated as professionals rather than as citizens. Lastly, even if we could rely on the legal definition of citizen, it would cause conceptual problems on many occasions. Similarly, even if the citizen-user dichotomy could be used to denote the previously mentioned dual roles of citizens in urban economic development, it would ultimately be difficult to sustain. Thus, even if we can usually distinguish between the previously mentioned paradigmatic roles of citizens as well as two ideal types of participatory settings, those of democratic forums and innovation platforms, neither of the demarcations are clear-cut. The conceptual boundaries are actually rather blurred in urban economic development, for the process may simultaneously involve political, resident, and user roles and facilitate innovative neighborhood planning in collaboration with city government, companies, universities, and citizens.

Among the most well-known typologies of citizen participation and influence is Sherry Arnstein's [79] ladder of citizen participation, which aptly describes some key aspects of participation viz. a representative system of government. Since then the number of models and typologies of participation has proliferated. If we add to traditional technocratic forms of citizen engagement in urban planning some new forms of involvement, ranging from open space technologies to pop-up planning and civic hacking or urban hactivism, we get a contextual view of the forms of participation, which starts from professionally controlled technocratic planning, continues to a higher degree of tokenism in professionally supported or facilitated collaborative planning and at the other end of the continuum shows a high degree of autonomy in self-organized ad hoc planning. The underlying assumption is that as a rule the higher the degree of autonomy and creativity, the lower the integration in official planning system. This scheme is illustrated in Figure 2. 


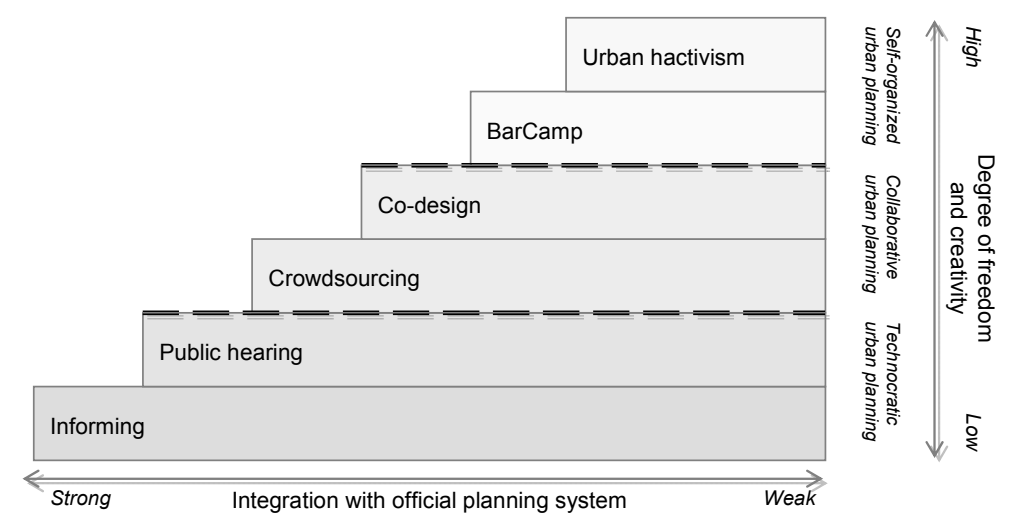

Figure 2. Degrees of integration and creativity in urban planning.

Citizen involvement in platforms for urban economic development requires a context-specific theorization. A classic approach in product development is to identify the degrees of involvement: design for users, design with users, and design by users [80]. An analogous scheme applied to urban planning has been developed by Sarah C. White [81]. Her heuristically powerful model of the forms and functions of participation includes four forms all based on different rationales: (a) nominal participation is used by powerful urban regimes to give legitimacy to development plans and projects; (b) instrumental participation is primarily a means towards a pre-decided end, which often enhances the utilization of community assets and human capital; (c) representative participation gives community members a voice in the decision-making and implementation of policies that affect them; and (d) transformative participation results in the empowerment of those involved, which, as a truly decentralized manner, potentially leads to radical changes in community life. Each mode of participation is an expression of some basic function, which we may call, respectively, display, means, voice, and power to change. This scheme is illustrated in Figure 3.

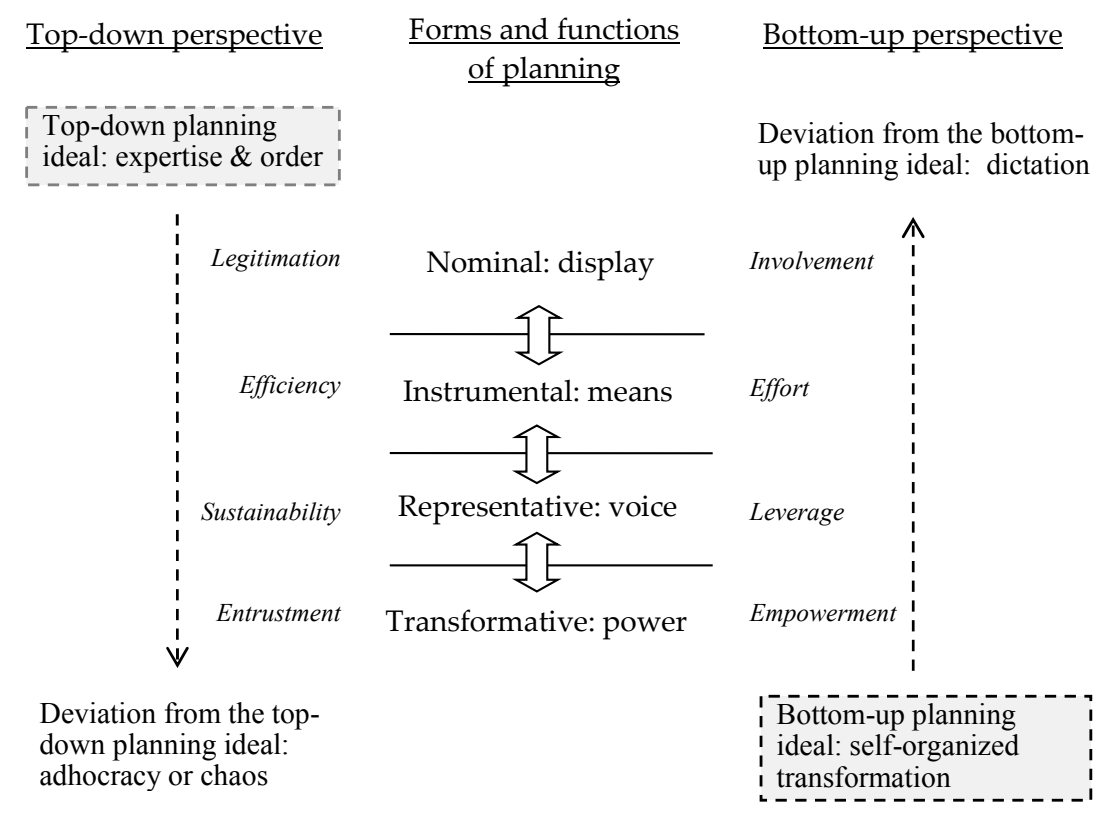

Figure 3. Two perspectives on participation in urban planning (adopted from [81]).

The main idea of Figure 3 is to illustrate that the value stances behind the top-down and bottom-up planning models have reversed understandings of the planning ideal or "equilibrium" and different interpretations of the forms and functions of planning. White [81] looks at this issue as a power game 
and develops her model further by describing how the bottom-up interests of people and communities and the top-down interests of urban regime and growth coalition relate to the modes of participation. Top-down interests seek legitimation, efficiency, sustainability or empowerment, the latter in the sense of entrustment or delegation, depending on the form of participation, whereas bottom-up interests have to do respectively with inclusion, effort (alternative cost), leverage and empowerment. Both of them relate to the forms and functions of participation, creating thus a dynamic field of the politics of participation, as illustrated in Figure 3. On this basis, we can obtain a theoretically-oriented view of how nominal, instrumental, representative or transformative participation is in each case, and how each of them relates to the dialectics between top-down and bottom-up interests in urban development. It is worth remembering that it is not always self-evident who benefits from each planning initiative and how [82]. At the concrete level, the question is, for example, how will the real-estate business, the political regime, the creative class, the middle class and disadvantaged groups contribute to and benefit from stakeholder-engagement in urban economic development.

\section{Findings}

This section discusses three smart city cases in order to shed light on the forms and implications of platformization. Concerning the national context, the smart city development model has become an integral part of Finland's innovation-driven economic development policy [83]. The role of cities has increased on this agenda, reflecting the developments sometimes referred to as metropolitan revolution [84]. At national level the most important program that reflects this trend is the Innovative Cities (Innovatiiviset kaupungit, INKA) program for 2012-2020 designed to expedite the emergence of innovation hubs in Finland. The other key program is the Six City Strategy-Open and Smart Services (abbreviated to 6Aika in Finnish) for 2014-2020, which is a strategy for sustainable urban development implemented by the six largest cities in the country: Helsinki, Espoo, Vantaa, Tampere, Turku and Oulu. The strategy has three focal areas: open innovation platforms, open data and interfaces, and open participation and customership. Forum Virium Helsinki is responsible for the national coordination of the Six City Strategy [22].

\subsection{Helsinki-A City as an Open Living Lab}

The city of Helsinki is the capital of Finland, the largest and most internationalized city in the country. Its current strategy, the Helsinki Strategy Program 2013-2016, envisions a city that is a world-class business and innovation hub, whose success benefits the welfare of its citizens and the whole nation. It is a crystallization of the balanced approach of the city to development issues: "Partnerships between business community and the city government are promoted so as to strengthen environmental responsibility and create innovative and new business around smart technologies, resource-efficient services and carbon-neutral products". The strategy refers to Kalasatama as a model area for smart urban construction. Openness and participation are seen as crosscutting principles to be applied in all major activity areas. A special smart city-related aspect of openness and participation theme is open data, to which Helsinki pays a lot of attention in order to increase innovativeness and to design better services [18].

Even if municipalities have traditionally been independent and born the responsibility for their own development, the cities of the metropolitan region have started to collaborate on economic development, which includes the drafting of a joint innovation strategy [21]. Its overall objective is the success of the metropolitan region in global competition through the intensification of collaboration between the key institutional actors and better mobilization of innovation potential of the region. It is an instrument for the realization of the vision of Helsinki Region as a world-class innovation hub based on science, arts, creativity and learning capability and on the power of good service, which benefits citizens in the region and indeed Finland as a whole (on the innovation environments in Helsinki, see [85]). 


\subsubsection{Forum Virium Helsinki}

Forum Virium Helsinki was set up in the mid-2000s on the initiative of the business community. The motivation was to support the creation of new business opportunities both domestically and internationally through a shared platform, thematically focused collaboration, and product development [86]. Forum Virium Helsinki is a stakeholder-involving innovation consortium of the city of Helsinki. Its organization has from the beginning been based on ideas of partnership and openness. It has a management board led by the city government, a stakeholder-involving steering group with considerable power and stakeholder-involving working group, the latter having responsibility for the operational management of programs and projects. Practical work relating to management, finance, information technology, communications, and thematic programs is organized by the office of the Forum [87]. Its budget rose from 1.3 million euros in 2006 to some 3.2 million euros in 2013. The idea is that the city of Helsinki covers the basic costs, while projects are funded separately from various sources. For example, in 2013 the Innovation Foundation of the City of Helsinki covered some 30\% of the Forum's budget, the rest being covered as follows: project funding from various sources (EU FP7, ERDF, ESF, Tekes, etc.) some $48 \%$, commissions from Helsinki and other municipalities of the region $20 \%$ and membership fees of companies $2 \%$ [88].

The main goal of Forum Virium Helsinki is to develop the essential building blocks for smart and open cities of the future. A concrete aim is to create better services, new businesses, and to forge links to international markets. The Forum itself has been characterized as an innovation platform which develops needs-based and internationally competitive digital services in collaboration with private businesses, public organizations and citizens in the Helsinki metropolitan area [87]. It has proved to be at its best in building bridges between the public and private sectors. Its development projects reflect such bridging, for they are primarily designed to solve problems in the public sector, but solutions are developed in collaboration with private enterprises and residents of the city. It reflects a new urban development paradigm in the sense that the development of local public services starts from the everyday lives and needs of citizens, and from an intention to develop services that really make everyday life easier [88].

Forum Virium Helsinki's core activity is to manage development projects. The activities of the Forum focus on the following: smart city, new forms of media, growth company services, and innovation communities (living labs). From the platform perspective, two of these are particularly interesting. First, the Smart City Project Area is involved in the development of digital urban services that make traveling and living in the city easier. These services include among others real-time traffic information for citizens. Another mission within this project area is the opening up of public data. With open access to public data, new and more versatile services are created by individuals and companies. Lastly, this set of activities focuses on testing smart city services in the real-life setting of Helsinki metropolitan area. The goal is to keep the capital region as one of the leading testing environments for digital services (see [89]). Another project area of special importance for citizen involvement is known as Innovation Communities. This family of activities tests and develops user-driven innovation processes, methods, and tools. It brings together companies, public sector organizations, research institutions, and citizens. Together they make up an ecosystem where the best practices are shared (on the Innovation Communities of the Forum Virium Helsinki see [90]).

\subsubsection{Living Labs}

Smart city initiatives of Helsinki have been framed by the regional innovation strategy. Smart city initiatives are multidimensional, though mainly built on cluster policy and user-driven innovation. One of the most characteristic means of implementing user-driven innovation in the region is the Living Lab concept [51] (pp. 104-105). The Helsinki Living Lab network was set up in 2007 to meet the challenges of product development. It provides a platform that aims at promoting user-driven methods and tools for improving the real-world development of products and services [86]. Helsinki Living Lab is also a communications hub and a brand to enable companies and the public sector to get in touch 
and cooperate with all the different Living Labs in the Helsinki metropolitan area [91]. Their profiles vary but they all rely on user-driven innovation.

Living Labs serve as magnets in the innovation ecosystem: city governments use them to promote economic development by generating social, service, and governance innovations; higher education institutions use them to bring their teaching and research closer to developers and users; and innovative companies use them for ideation, testing, and product development. Through such a diversity of engaged actors and the principles of openness and co-creation, Living Labs actually do a great deal to shape the entire idea of smart city in the metropolitan region [53].

\subsubsection{Spearhead Projects and Platforms}

Numerous smart city programs, platforms, and projects have resulted in smart city "buzz" in the capital region. For example, Smart Kalasatama is to become a model for building a sustainable smart neighborhood; Helsinki Region Infoshare (HRI) provides public data for anyone to use in their applications; Open Ahjo is an interface that provides access to the documents of the city of Helsinki; Helsinki Loves Developers organizes developer meetups and a portal (dev.hel.fi); Open Finland Challenge is an innovation contest; CitySDK is an open data interface project; D-CENT offers citizens and associations open-source platform and tools for organizing their activities; and Code for Europe provides creative people with opportunities to work in innovative cities [76]. All such smart city initiatives are expected to pave Helsinki's way to a smart urban future.

Smart Kalasatama, which is one of the development projects financed by the Six City Strategy program in 2015-2017, has a special role in Helsinki's smart city-inspired development portfolio. It is a Living Lab par excellence, referring to both a place where innovations are created and tested and a network of people who are involved in the process. The vision of transforming this old harbor into a smart city district is to be realized through experimentation, ICTs, and the use of open data. Its construction started in the late 2000s and will continue until the mid-2030s [92]. It was branded as a designated smart city project in 2013. Smart Kalasatama includes various activities that bring business and civil society together. A major attempt at stakeholder involvement is Developers' Club, which started to attract key people from government, business, and civil society interested in the development of the area in 2015. Developers' Club is convened four times a year. From 2016 to 2017 the Agile Piloting program provides modest financial support to some 15 to 20 collaborative short-term experiments in order to develop promising ideas into service innovations and new business. An application area that relates to sharing is Flexi Spaces project, which smartens up the use of premises in the Kalasatama area by providing a reservation system through which inhabitants can rent club rooms, saunas, negotiation rooms, and classrooms. This is expected to increase both livability and entrepreneurship in the area $[93,94]$.

Citizen involvement in innovation-driven business is promoted by a large number of open data projects. A flagship project that reflects a genuine smart city idea is Helsinki Region Infoshare (HRI), which has promoted the utilization of public data produced by the municipalities of the capital region since 2011. The result is more than 1000 public data sets opened for unrestricted use. An example of a popular database is timetables and route information of the Helsinki public transport operator. Such data have already been utilized in mobile applications developed by several small companies and enthusiasts. The opening of public data has been so extensive that Forum Virium Helsinki has withdrawn to the background of the project, for since the beginning of $2014 \mathrm{HRI}$ has been part of the conventional activities of the municipalities involved [88]. Another illustrative example of Helsinki's commitment to openness and sharing is the Open Helsinki Hack-at-Home (OH-HAH), a temporary collaboration platform set up in 2013 through which the city government sent an open invitation to software developers encouraging them to use open data for the development of relevant service applications. The focus was on finding solutions that help to respond to challenges relating to transparency in decision-making, feedback from citizens to city government, and the need to improve visitors' experiences of the city [95]. An example of the fruit of such open availability of data is 
BlindSquare [96], which was developed in collaboration with visually impaired people to facilitate their everyday lives by helping in locating oneself and finding sought-after destinations [93].

A primary example that combines business-citizen interaction with sustainable development is the Climate Street Project coordinated by the Environment Center of the city of Helsinki [97]. It is also part of the Six City Strategy and co-financed by the EU. The project develops sustainability in a focused manner in the built environment of two places, Iso Roobertinkatu in Helsinki and in Tikkuraitti and Asematie in Vantaa, with the aim of reducing energy consumption and greenhouse gas emissions. Firms, real estate owners, and inhabitants of these areas are involved in creating and experimenting innovative solutions together with the city government [93]. To facilitate quick innovations, the Climate Street Project in 2016 commissioned three small-scale pilots-Sustainable Meal, Resource Efficient Existing Buildings and Zero Food Waste- to be piloted in Iso Roobertinkatu street under Smart Kalasatama's Agile Piloting program. The program also involves inhabitants and private housing companies in the planning of climate-sensitive green yards. There are also plans to facilitate citizen involvement through joint purchases based on local needs and, related to this, to support integration through the activities of a joint business and residents' association [98].

\subsubsection{Citizens and Users in Focus}

In Helsinki's approach to innovation the city itself is seen as an open innovation environment, which is an extension of the idea of Living Lab. Smartness in such a context is more than just advanced infrastructures or state-of-the-art technological solutions. For Helsinki, the making of a smart city signifies advancing the open engagement of citizens and communities, pioneering in open data and transparency, and promoting agile service development, as described by Jarmo Eskelinen, CEO of Forum Virium Helsinki [86]. This implies that citizens are involved in different roles and their involvement has different functions; some projects giving them a voice, some securing their rights as political actors, and others utilizing their knowledge and experience as service users. Such a variety is visible in the projects of Forum Virium Helsinki. Even if the Forum has not designed a process model to guide its operations, it has collected the lessons of successful projects, such as the previously mentioned HRI, into "the anatomy of successful development project", which comprises five elements: (1) identify problem; (2) ensure commitment of key partners; (3) involve users; (4) test; and (5) improve and collect feedback. The Forum is a unique development unit of a city in the sense that it has adopted some work methods of small software companies. It is also agile in its policy of taking prototypes quickly to the testing phase [99].

The Forum actually implements the strategy of the city of Helsinki by promoting openness, democracy, and inclusion. One example of the decisive steps in this area is the HRI project mentioned above and its pioneering work in the field of open data. A more proactive role is exemplified by projects such as D-CENT intended to create new web-based tools and participatory platforms for citizen collaboration and open interaction between public authorities and citizens.

The picture obviously also has a commercial side, which approaches citizens primarily as customers, consumers or users. User-centered open innovation is the key to the way of working of the entire Forum. Services are developed and tested together with the users and application developers. For example, the Walk and Feel Helsinki project was initiated in the summer of 2011 to help cruise passengers to become acquainted with Helsinki and provide them with a new way to explore the city. The next year, an extended Walk and Feel Helsinki service was launched, placing NFC tags at every tram stop to enable passengers and tourists to receive information about the next tram's arrival (see [100]). The city's infrastructure and services are built step by step through various smart city projects, which eventually both increase the smartness of traffic, facility control, and other aspects of urban life, and support the development towards a genuinely open city.

The plethora of newly initiated projects and platforms reflects the strategic plans of the city to make Helsinki a genuinely smart city. However, whether they can be called successful varies case by case. As most of them are on-going or recently completed projects, their evaluation is not meaningful. 
We can say, however, that participatory platforms have created local enthusiasm and given indications of their potentially important contribution to local economic development, which is built on the match between the strengths of the city and the prevailing global techno-economic trends. If it tells anything about the results, Helsinki is highly ranked in many relevant city rankings [101]. For instance, the CITIE Index 2015, which surveyed the level of support to innovativeness and entrepreneurship in 40 cities worldwide, ranked Helsinki third, the two leading cities being New York and London [102]. Similarly, in several rankings and league tables of entrepreneurship, startupping and high technology, Helsinki ranks fairly high [101]. These references are obviously not irrefutable evidence of success as such, but when various rankings are combined, they suggest that Helsinki has relational strength as a city of innovation and entrepreneurship.

\subsection{Tampere-A Stakeholder-Involving Open City}

Tampere is one of the largest cities in Finland with some 225,000 inhabitants. It started to industrialize in the first half of the 19th century. The city's industrial heritage is expressed in one of its nicknames, "Manse" or the Manchester of Finland. Such a heritage determines Tampere's approach to the smart city challenge, which puts emphasis on the renewal of manufacturing firms, exploring advanced manufacturing technologies, smart specialization, and the need to strengthen a range of postindustrial activities. In her preface to Tampere's current city strategy, Tampere: Working Together for a Bright Future-Tampere City Strategy 2025 [19], the Mayor of Tampere stated explicitly that Tampere is to be developed into a smart city. In the vitality and competitiveness section of the strategy one of the key strategic priorities is expressed as follows: "The city will invest strongly in economic, industrial and innovation policy. The renewal of economic and industrial life is based on smart growth, i.e., high levels of competence, active research and innovation, and efficient use of new technology". The strategy places emphasis on innovation environments designed to serve particular economic sectors, including the creative sector, ICTs, health technology, and the media sector, which are of vital importance for the city's restructuring efforts. Just like other large cities in Finland, Tampere aims at balanced development, i.e., business development is balanced with promoting democratic participation, closing the gaps in well-being, and fostering sustainable development [19]. Its business promotion is vested in the regional economic development agency Tredea [103].

\subsubsection{Open and Smart Tampere}

Tampere has based its restructuring on a range of partnership-based economic development programs. Operating on a partnership basis eTampere (2000-2005) developed the digitalization of the economy, governance, and social life [104]. BioneXt (2003-2009) was an investment and development program that focused on biotechnology by combining the strong technological expertise in the Tampere region with new biological and medical research, especially in three areas: biomaterials and tissue technology, Bio-ICT, and immunology. As a reflection of Tampere's need to break away from its industrial past and technocentric orientation, in the latter half of the 2000s its economic development policy was guided by Creative Tampere program (2006-2011), which aimed at creative urban design as well as the development of creative industries. All these programs signify changes in the local understanding of the basic needs and directions of economic renewal. They also indicate some changes in the approach to citizen participation, as at the time of e-Tampere the core issue was access, skills, and motivation of citizens to use new digital services [105], while Creative Tampere marked a shift towards creativity, sharing, and co-creation, to be further enhanced in the current economic development program, Open Tampere (2012-2018). The last of these is a kind of integrative local framework program, or in more practical terms a "project machine", which contributes to the birth of new growth-oriented companies, creates global business, and promotes the restructuring of existing industries. Its reliance on openness hints at an understanding of the need to focus on open innovation in promoting economic development. 
Tampere's current aspirations in economic renewal are best expressed in the recently published OPEN/SMART/CONNECTED (O/S/C) strategy originally produced for the iCapital application, which is actually based on the previously mentioned Six City Strategy. It builds on the same three key elements that frame the work of the Six City Strategy: open innovation platforms, open data and interfaces, and open participation. The $\mathrm{O} / \mathrm{S} / \mathrm{C}$ strategy aims at further scaling up the three core elements to create service innovations, new jobs, and companies through practice-oriented pilots. The special focus of the scaling up activities is on the co-creation of health and well-being service innovations and on the promotion of citizen participation in the Tesoma district in Tampere. The latter represents an innovation-driven urban renewal, including an urban district-focused innovation platform, "Oma Tesoma" [My Tesoma], which was set up in 2013. Tesoma is a suburb of Tampere with some 20,000 inhabitants. It is the first district-wide case of O/S/C strategy, which integrates innovation platform activities into urban development policies and projects. It aims to attract companies, residents, and local communities to create service innovations, business opportunities, and attractive living environments [106].

The Open Tampere program has created "innovation factories" as spaces, operational models, and communities that permit fast innovation by bringing different actors together. The aim is to create new business and hence new job opportunities. Such thinking indicates a transformation towards platform-enabled local innovation policy. Accordingly, the focus is on small firms and start-ups, new digital economy, urban innovations, and smart city solutions, which are enhanced by open innovation platforms. The most important innovation factory is the so-called New Factory (Uusi tehdas in Finnish) accompanied by a few other innovation platforms [107]. New Factory is a paradigmatic example of recent trends in the creation of a new generation of innovation platforms with several platform-style micro-environments to support ideation, prototyping, and the utilization of user experience. Konela ("Kone" is machine in Finnish) is an innovation center for mechanical engineering and energy technology. The Institute of Biosciences and Medical Technology or BioMediTech is an institute specialized on biotechnology set up by the University of Tampere and Tampere University of Technology (TUT). Beside integrating and strengthening the local tradition of excellence in basic life-science research and teaching, it serves as a platform for discovery and innovation. Later in 2014, a more recent creation, Mediapolis, has been brought to this same scene to support the development of a mini-cluster in media industries (see [108]).

\subsubsection{New Factory and Demola as Stakeholder Engagement Platforms}

New Factory represents a new fashion in platform governance that contributes to the broadly understood local economic restructuring. It was set up in 2010 with the backing of numerous local and national organizations, including the city of Tampere and surrounding municipalities. It is a proactive response to Tampere Region's need for structural change by creating a large number of new businesses, new jobs, and know-how about international growth business [109].

The mission of New Factory is not primarily to support the R\&D of established firms, but rather to provide a multi-faceted innovation platform to help in creating new business. It connects business and people and facilitates their interaction on several platforms and sub-programs by providing premises, tools, facilitation, and expertise for collaboration. New Factory offers innovation matchmaking, mentoring, accelerator, and coaching services for start-ups, and two special innovation platforms, Demola to involve university students in creating demos and Protomo for prototype-driven startupping [110]. Due to its open and inviting working culture and excellent local visibility, New Factory has created a lot of optimism and innovation-related buzz in the city [45].

At the very heart of New Factory there are principles like openness, sharing, learning, creativity and co-creation, which have found their purest expression in one of its platforms, the student-engaging Demola. Demola was set up in 2008 as one of the projects supported by the Creative Tampere program (2006-2011) and was later taken under the wing of New Factory. An important factor behind its establishment was the fact that the city with 220,000 inhabitants has some 38,000 students, with vast 
latent potential for urban economic development. We are not discussing here a conventional Living Lab, for while the latter incorporates the wider community in product and service development, Demola mainly involves students. The other difference is that instead of testing new products, which is typical of Living Labs, Demola focuses on generating concepts and creating demos and prototypes [111].

The projects organized in Demola fall into such thematic categories as business concepts, software, design and art, education, engineering, environment, governance, health care, media and communications, and social science. In Demola's work, the smart city concept is one of the integrating themes, as many of the projects suggested by public and private organizations point in this direction. One expression of this interest is the Smart City accelerator initiated in 2014 in cooperation with the city of Tampere and the cities of Malmö and Lund in Sweden. It aims at finding through smart application a smart city platform for the creation, testing, and utilization of meaningful solutions and services, envisioned to reflect the idea of a sensing city that "feels and moves alongside its citizens" (see Smart City accelerator at [112]).

What university students do in Demola is essentially to create demos or prototypes of novel ideas and services or products in response to problems brought to the platform by local companies or other organizations [113] (p. 30). University students form ad hoc teams to create innovative solutions to such real-life problems [111]. Students are recruited for Demola on the basis of their own motivation and areas of interest. They can apply for available projects a few times during the academic year. Through participation they earn credits for their degrees and occasionally also receive monetary remuneration, depending on the value and potential of the results of their work.

Since its establishment Demola has served as a platform that has involved more than 150 partner companies with their needs for new concepts and solutions, and at the other side of the equation, has gathered some 2000 students (of whom some 35 to 40 percent are international students) working in teams for projects, of which some 350 have been completed so far (in 2015). One of the core principles of Demola is to reward those who contribute to the projects. This has led to a policy according to which the teams of students own the results of their work, which gives them a chance to develop the ideas further and create their own businesses. In addition, a project partner may also license the results from the teams [111,114]. An indication of the success of the work accomplished in Demola is the high share of projects with licensed results (some $80 \%$ ) which has generated over 1 million euros for students in the form of licensing fees. Another indication of the success of the model is that many students are recruited after the projects (some 15\%) and that the willingness to become an entrepreneur rises considerably among participating students, on average from some $30 \%$ to $75 \%[45,113,115,116]$ (on the facts of Demola, see [117]).

However, such an innovation platform did not evolve without challenges. As students are not usually experts in the given field and the quality of their work varies from one project to another depending on the composition and dynamics of the group, irrespective of how hard the Demola facilitators try to guide them through occasional difficulties, some partners have at times expressed doubts about the usefulness of the platform. Another obvious challenge is generating trust among the team, as a lack of trust may be detrimental to achieving optimal results in co-creation [111].

All in all, Demola expresses well the open innovation-driven developmentalism at the heart of Tampere's economic renewal. It enhances local learning through the guidance and support provided to students by industrial and academic partners, the facilitation of co-creation and creative development of original ideas, which often end up with wider variety of applications and configurations than originally envisaged, implying a high degree of creativity in the value creation process [111-114].

\subsubsection{New Generation of Platforms in Tampere}

Innovation factories as stakeholder-engaging hubs in the city have been supplemented by various new innovation platforms since the launch of the Six City Strategy and the INKA Program in 2014. The overall aim of the city is to move from closed firm-based activities towards an open, collaborative, 
and user-centered innovation model, within which co-creation and service design processes are organized collaboratively by the city government, local business, universities, and citizens [118].

Probably the most illuminating example of this trend is Koklaamo (the Finnish project name refers to trial) set up within the Open Innovation Platform focal area of the Six City Strategy with the purpose of involving citizens in innovation-driven business development. This is an open innovation platform for user-centered and agile co-creation, which creates business opportunities for local small and medium-sized enterprises (SMEs), while at the same time encouraging the entire urban community to take a new role in and responsibility for improving the vitality of the city. The idea is to create business opportunities by meeting the particular needs of local inhabitants. The Koklaamo process was outlined at the beginning of the project. It includes four main phases: (1) identification of citizens' challenges, problems, and needs; (2) creating feasible solutions; (3) agile testing of the solution in a real urban environment; and (4) evaluation and follow-up [119]. It has decided to be piloted in two projects in the Tesoma district in autumn 2016, one of these developing new exercise solutions for parents and the other focusing on traffic safety. The initial plan is to later extend the model to other city districts, or even for it to be scaled up as a whole-of-city solution [120-122].

There is a range of other projects and platforms in which business-citizen integration and customers' views are taken into account, albeit in many cases only indirectly. One of them is the newly launched digital innovation voucher to be piloted in the latter half of 2016 [123]. A service design approach involving stakeholders is also applied in the promotion of electric transportation and in the EU-funded MoveUs project, in which end-users test multimodal journey planner application. Moreover, senior citizens have been involved in testing new home care applications, which contributes to product development in health technology [118]. These ideas are further developed within Six City Strategy framework in the Open Participation and Customership project designed for Tampere, which develops both user-driven service innovations and partnership models. An example of the latter is a model in which a product or service innovation is tested within the municipal service system, thus giving private providers valuable knowledge and a reference, while the municipal service that served as the test bed is able to learn from the experience and utilize it in service development. In such processes, citizens are primarily in the role of customer or user, even though by giving feedback, for example, their participation can be seen to represent a broader interest in local policy making and governance [122].

A category of its own in business-citizen integration is the redevelopment of neighborhoods or urban districts. Beside previously mentioned Tesoma, a good example is the partly EU-funded EU Gugle Project organized in the Tammela district, in which the city government coordinates development collaboration between privately owned housing companies, inhabitants, and the real estate business. The idea is to promote energy-efficient renovation demonstrations intended to create environment-friendly living spaces (see [124]). Another area-based case of the participatory culture associated with platform and sharing economy is Temporary Hiedanranta (Väliaikainen Hiedanranta, [125]), an old industrial district which is revitalized by attracting civic, cultural, and business activities. It was deliberately opened as a platform for civic and business activities before its completion with the idea that this is the way to utilize and reshape the identity of the area during the planning phase. The area will be developed comprehensively on the basis of an international ideas competition arranged during the latter half of 2016 [118].

All in all, citizen-centricity has an important role in creating opportunities for local firms, as has been seen in projects operating under the framework of the INKA Program and the Six City Strategy. Tampere's actions are consistently guided by strategic plans leading it towards the smart city vision. However, as we are talking about a new trend, the role of citizen engagement in innovation platforms is neither systematic nor fully integrated [126]. Tampere is going through a phase of trial and error, and is learning from its new projects [121]. New Factory and Demola have a slightly longer history than projects set up within INKA and the Six City Strategy, and in their case at least the outcomes have 
been positive [113-116]. Time will tell which participatory solutions eventually bear fruit and what their long-term impact will be on local economic development.

\subsection{Oulu-A Northern Partnership-Oriented High-Tech City}

The city of Oulu with some 200,000 inhabitants is one of the leading high-tech cities in the Nordic region. It brands itself as the Capital of Northern Scandinavia. Oulu's strength lies in the technological expertise built in the University of Oulu, the presence of innovative IT companies, proactive networking, and the promotion of high-tech industries by the business-friendly city government. This point is also visible in Oulu's brief city strategy, City Strategy Oulu 2020. As a whole the strategy document reflects the same balanced view as Finnish cities usually do. Its implementation is based on separate implementation programs, among which responsibility for economic development is assigned to the city government-owned enterprise BusinessOulu [20].

\subsubsection{The Premises of the Oulu Phenomenon}

The Oulu phenomenon refers to the special growth-oriented development spirit of Oulu at the height of its IT boom, mainly associated with the growth of the electronics and telecommunications industry and also of the software industry [88]. It evolved as a subcontractor model based on Nokia's role as a "locomotive".

The first technology center in Finland and at the same time the first of its kind in whole Nordic region, Oulun Teknologiakylä Oy, was established in Oulu in 1982. In three decades, it grew into a large real-estate and service company, renamed Technopolis, with an extensive network of business centers operating in eight cities in Finland as well as in Estonia, Russia, and Lithuania. It has plans to become a smart park company, which implies a transformation from offering premises and services to proactively creating and promoting an ecosystem of growth at its various locations [127]. Even if the media may have exaggerated its role in the development of Oulu, Technopolis had an undeniable impact on the development of the ICT-driven high-tech cluster in Oulu [128].

This model started to crumble in the 2000s, however. It has been said that the ICT cluster in general rested too long on its laurels created by its early IT boom. In any case, a result of Nokia's presence was a strong focus on telecommunications and mobile technologies. The proactive approach to business promotion by the city government led to the establishment of several networks and platforms designed to support IT firms' need for testing, R\&D, and commercialization [129] (see also [130]).

In times of economic downturn, Oulu has constantly relied on its partnership-based governance model, reflected in the Oulu Growth Agreement adopted in the early 2000s and the Innovation Strategy for 2007-2013. Recent developments show clearly that Oulu is developing from "innovation hub" towards "innovation node" in the sense that many of its major projects are based on extensive collaboration with other Finnish cities within the national Innovative Cities (INKA) program. It has also boldly expanded its international operations by setting up business centers (Finnish Business Hubs) to facilitate connections between Northern Finland and the target country, the three current centers being in Astana (Kazakhstan), Gällivare (Sweden) and Tromsø (Norway).

\subsubsection{Open Platforms for Technopreneurship}

Oulu has developed several platforms to serve product development. For example, OuluHealth Labs offers companies a unique testing environment for health product development [131], the 5G test network enables the development of new technologies and their testing in a real-life environment, and the MAPGETS portal offers an open-source 3D application platform aimed at both developers and professionals [132].

Oulu is an entrepreneurial college town, which is apparent in its initiatives. For example, BusinessKitchen is a joint center for entrepreneurship for the University of Oulu and Oulu University of Applied Sciences designed to promote student and research-driven entrepreneurship and to bring university students closer to companies [133]. Takomo is an open platform for professionals considering 
setting up a startup [134]. Demola Oulu brings together students from local universities utilizing the model developed in Tampere [135]. An additional indication of the entrepreneurial spirit of Oulu is the Oulu Entrepreneurship Society (OuluES), which is an open self-organized community for students interested in entrepreneurship and self-improvement.

\subsubsection{Citizen and User Involvement in Oulu}

The backbone of Oulu's user involvement is its pioneering effort to provide free access to a wireless network for all, which has maintained its relevance in spite of the development of mobile data networks [136]. The PanOULU (public access network OULU) network was created in 2003. In its coverage area it provides free wireless broadband Internet access to all at hot spots located mainly in public spaces. The PanOULU network is provided in cooperation with the city of Oulu and several educational and research institutions and companies [137]. Today, it is an important part of the multi-channel service infrastructure of the city and its smart city brand. It symbolizes not only expertise in wireless technologies but also partnership-based development and belief in inclusion and citizen engagement. The city government has a decisive role in keeping such an infrastructure alive.

Free WLAN has been one step towards inclusive city, the other being citizen involvement and information society-oriented civic education. In the 2000s, the city developed various open innovative environments for developing and testing new mobile applications (e.g., the Octopus Project) and launched several mobile service pilots, such as mobile library services, fishing permits, parking payments and dental appointments as a part of the city government's systematic attempt to develop flexible multi-channel solutions to public service delivery [137]. This development reflects the symbiotic relationship between the city government, the high-tech business, and service users. As already articulated in its Innovation Strategy 2007-2013, the city government stresses the importance of enthusiasm as a source of innovation. This does not mean only heavy users or digital natives but more broadly citizens of all ages living in different parts of the city [138].

Currently both OULLabs, and more so PATIO, are the most relevant instances of platformization, which facilitate interaction at the intersection of citizen participation and business development [139]. OULLabs or Oulu Urban Living Labs is managed by the University of Oulu. OULLabs provides a range of services, tools, and testing environments (UBI screen, 3D virtual labs, display site in the library, LeaForum research infrastructure, and CNL convergence laboratory) and occasionally also utilizes the PATIO platform. It facilitates the development of products and services in a real-life environment in collaboration with end users (On OULLabs, see [140]). Paradigmatic cases are R\&D or testing projects initiated by local companies, in which local people are involved as customers or users. It also organizes projects including the development of public services, as in the case of a remote-enabled public service project which developed alternatives to face-to-face services in collaboration with citizens, employees, and authorities in Oulu and a few neighboring municipalities [141].

PATIO is an online user forum or platform, and is used both by firms and the city government. It is a combination of a citizen forum and a Living Lab platform. It grew out of an EU-funded project of the city government and is currently being developed within the Open Innovation Platforms program of Six City Strategy (2015-2018). The underlying idea of this platform is to give citizens a chance to participate in the development of products or services they really need or of those that do not work properly. It invites everyone to get involved through surveys, focus group interviews, test groups, and similar activities (On PATIO, see [142]). PATIO has adopted the process flowchart applied to a typical product or service development project initiated by a company or other organization. It includes the following steps: (1) contact; (2) negotiations; (3) planning; (4) implementation/tests; (5) analysis; (6) report; and (7) result [143]. It points to PATIO's nature as a user forum that involves ordinary people in product and service development.

Let us take some examples of typical projects. In December 2015 families were selected to test the Snowfox trackerphone developed by an Oulu-based company giving parents real-time information on the whereabouts of their children. Feedback from the families involved was vital in ensuring that the 
product meets the needs of end users. In January 2015 users in PATIO were invited to participate in a workshop in which they were able to learn about and comment on applications of firms selected to join the EU-funded FICHe e-Health accelerator program. In spring 2013 PATIO was used as a platform for a citizen survey concerning the development of the Hiukkavaara area, and as a part of the same process a selected test group participated in an event which presented the modeled zoning of this area in the 3D Virtual Laboratory CAVE at Oulu University of Applied Sciences (On user experiences in participating such test environment, see [144]).

Even if the utilization of participatory platforms has actually a fairly long history, in the big picture its impact on the design of public services and on everyday life of citizens is still fairly modest, and the same can be said about the factual level of business-citizen interaction [145]. It seems that Oulu's successful partnership model primarily reflects Triple Helix (government, business and university) collaboration. It involves citizens primarily as customers or users, leaving their other roles in local economic development underdeveloped. In this process the role of PATIO has been invaluable [139]. Just as in Helsinki and Tampere, many ongoing urban development projects in Oulu embrace community and resident participation, a prime example being the town planning of the Hiukkavaara area and the related INURDECO Project. However, in most cases such projects follow democratic procedures with an emphasis on the partnership between the city government and the residents of the neighborhood, business being only indirectly involved through landowners and real estate companies, local retail and service businesses, and various solution providers [146].

\section{Discussion}

Leading Finnish cities have systematically developed their transformative capacity and smartness in order to facilitate economic renewal. A distinguishing feature of this process is the enhancement of citizen and stakeholder involvement in innovation platforms that reflects an attempt to democratize innovation-driven urban economic development. Such an emphasis goes hand in hand with the participatory turn in urban governance, policy making and town planning, which makes it plausible to assume that they are mutually reinforcing factors in community life, contributing to social and economic inclusion.

Let us start to elaborate this matter from the perspective of citizen participation. Citizen participation is undeniably an inherent part of the picture of evolving new governance [147]. Even if its benefits in local policy making and governance are usually taken for granted, it bears fruit only under certain conditions [148]. If such conditions are not met, it may become a Trojan horse that only legitimizes the aims of vested interests or local elites [149] or a setting that reproduces inequalities [150]. The question of the role of participation in the context of urban economic development is more complex than appears at first sight. First and foremost, the question of openness and co-creation of innovation becomes ambiguous if assessed against the principles of participatory democracy. As noted by Santtu von Bruun, Head of City Competitiveness Development Unit of the city of Helsinki, the idea of integrating democratic citizen involvement with the promotion of economic development is conceptually fuzzy. Democracy as such is not an issue in the promotion of business development. Rather, in the co-creation of new products and business models, the citizen fits into the picture as a customer, consumer or user. This relationship is not black-and-white, however, as has been seen in flexible use of spaces and some other cases in Helsinki [93]. In any case, a standard view of the role of key stakeholders' involvement in innovation platforms assumes straightforwardly that a firm's primary interest can be reduced to product development, while a citizen's role is to assist them by providing customer or user view of the concept or prototype. Our empirical cases suggest that an extended view of citizen involvement is required as citizens can directly and indirectly enhance entrepreneurship and create business opportunities by participating in open data projects as well as in urban revitalization and neighborhood development projects. Citizens' role becomes undoubtedly more problematic in direct involvement in the formulation of economic development policy due to a lack of knowledge and experience in business development, even though in this policy field, too, 
they should be entitled to have their say, if nothing else, at least through their political representatives. There is actually a concept that challenges such a narrow view of citizen involvement in the design of economic development policy: the wisdom of crowds [43,44]. That is, the potential of crowdsourcing or citizen-sourcing [151] has been overlooked by experts in local economic development policy, even if citizens through their diverse backgrounds, views, and experiences may actually bring fresh ideas about the challenges of and policy options for economic development (cf. crowdsourcing in urban planning, see [152]).

To open up a broader perspective on this matter, we need to consider the societal conditions within which firms organize their R\&D activities and the culture that embraces the launch and performance of innovation platforms. The general interest in economic development and the need for economic renewal can be seen as a unifying interest among the members of local community, which provides a starting point for the constructive side of citizen involvement in local economic development policy. On the constructive side of this picture we may discern the emergence of new opportunities for all parties involved as well as diversification of the governance field, especially in terms of new intermediary roles for involved organizations and genuine plurality that grows out of grassroots participation. At best such processes become triggers that strengthen the "participatory turn" and even go beyond that, supporting a parallel development of civic and associational initiatives, networks, and new forms of action outside the institutionalized public domain [153]. In all the cities discussed here participation is a core element of public governance, which is extended to innovation-oriented economic development policy through participatory innovation platforms. It reveals the duality of participatory structures due to the co-existence of instrumental and representative modes of participation, as evidenced in the practices of New Factory and Demola in Tampere and OULLabs and PATIO in Oulu, all of which have a professional approach and a step-by-step view of their core processes. The general impact of such participation is conducive to the utilization of local innovation potential and thus potentially to local economic development, which ultimately benefits the whole local population.

A critical perspective on the development of participation through ad hoc arrangements and projects emphasizes the instrumentalization of participation, which allows only little room for affecting the conditions of participation, agenda-setting, and continuation after the termination of the project $([153,154])$. Within such a framework citizen and user engagement can be seen as a way to enhance productive processes and, in a sense, to outsource the issue of participation to innovation platforms, which actually leaves the fundamental aspects of public governance intact. We may thus ask how much the settings, processes, and expected outcomes are predetermined by local growth coalition and harnessed initially to serve the accumulation of parochial capital [82].

Smart city as a conceptual development model was originally launched by global consultancies and technology enthusiasts and later adopted by local developers, which explains its narrow initial focus [33]. The concept has been broadening for many years, partly due to the severe criticism of smart city-oriented new town projects [154], suggesting that there is a need for a multi-dimensional, collaborative and citizen-oriented conceptualization of smart city. Such a view also broadens the framework for participatory innovation platforms. Accordingly, the building of innovation platforms is perceived as a process that goes beyond the narrow motive of firms' product development; rather, it is seen as a vital part of urban innovation ecology that facilitates various aspects of business-citizen interaction, which in turn has a potential to contribute to economic development.

Inclusive and open platforms that facilitate business-citizen interaction are expressions of the mutually reinforcing relationship between democratic culture and business development. The cases of Helsinki, Tampere, and Oulu are examples of such balanced platformization. A factor that relates to both sides of the equation is open data and knowledge sharing. Smart utilization of transparency, open access to government information, and the strong support to open data development not only increase openness and transparency in society but also create business opportunities for IT enthusiasts, consultancies, start-ups, and established corporations. "Open data" itself is a scheme that facilitates business-citizen interaction. The other area in which these two sides are present is the development of 
public services: when innovation facilitation is extended from firms' product development to public services and governance, it contributes to the development of publicly-funded services that are efficient and meet citizens' needs. The process itself and the related outsourcing option may also create new business opportunities for private providers. Lastly, a special instance of business-citizen interaction is innovative urban development, in which active and innovative citizen involvement has potential to improve the conditions of retail business, promote the business of consultancies, software companies or other local SMEs, and invigorate the real estate sector.

These three points of business-citizen interaction-open data, public services and urban development-are discernible in the cases of Helsinki, Tampere, and Oulu. All of these cities support open data and knowledge sharing, focus on the development of public services through platforms within the smart city framework, and have utilized innovation platforms in neighborhood revitalization. It is obvious that "citizens" are in most cases customers or users, but on many occasions citizens are also either residents of the city who are empowered in the development of the areas in which they live, as in My Tesoma in Tampere, Smart Kalasatama in Helsinki or Hiukkavaara in Oulu, or citizens whose needs and views give impetus to the design of local services, as in the cases of Forum Virium in Helsinki, Koklaamo in Tampere and PATIO in Oulu. Participatory culture may be most lively in Helsinki, which has been characterized as a trailblazer of urban culture in Finland [155]. Helsinki also shows strongest signs of transformative participation, especially in open data projects, which reflects von Hippel's idea of practices which make innovation more "democratic" [6].

The assessment of the citizen participation in innovation platforms becomes more nuanced if it is analyzed within the framework of the political economy of local government [156]. One of the policy transformations with obvious impact on localities is cities' gradual change in their policy orientation from welfare provision through publicly-funded services towards a more outward-oriented growth policy, which hits the most vulnerable groups in the local society hardest $[157,158]$. Such a polity can be labeled neoliberal city, built on such premises as individual freedom, free market economy, and small government $[159,160]$. In smart city development its illustrative developmentalist variant is a corporate smart city, a new town endeavor driven by the profit seeking of globally-oriented high-tech and real estate companies and facilitated by entrepreneurial urban governments, ultimately leaving little room for ordinary citizens to participate in its making and accommodating mainly entrepreneurial, professional and well-to-do people [154]. It has been claimed that an unrestrained market-led approach has potentially detrimental consequences for the economic fabric of cities as well as for the quality of life of the residents [161]. In such a context participation in innovation platforms serves primarily two functions: instrumental participation supports innovation-driven business, while nominal participation legitimizes the neoliberal economic order. Such a market-driven development in its own way enhances the development of the crowdsourcing paradigm and the democratization of innovation [6,51,151], although this "democracy" is thin as it is confined to participation in a business-driven innovation ecosystem and its solidarity structures are assumed to work indirectly through trickle-down economics [162]. Such a narrowly defined innovation-for-all approach undoubtedly helps active and capable citizens to become part of the innovation-driven economy. It suggests, however, that there is a critical shortcoming of such a smart city discourse, for issues like urban poverty and inequality are not discussed within it at all [163].

Such a view reveals a suppressed structural tension that points to the contradictory aspects of local economic development as theorized in urban regime theory [164] and more so in the growth machine thesis [82]. There is, however, a need to see beyond such frameworks as they have difficulties in explaining the occasional socially-motivated solution or urban sustainability compromise, as in the case of the smart growth program in Austin, Texas. Austin's ability to sustain growth while pursuing sustainable city development was an institutional innovation that emerged as a result of struggles between the business community and local environmental activists $[165,166]$. Tretter [167] claims, however, that in this particular case, the institutional compromise actually shifted the costs of growth from the "ecological" onto the "social" through the city's homeless population. 
Another major implication of such a structural tension is people's tendency to organize social action outside the domain of the neoliberal urban regime by hacking the city [168]. Civic hacking builds a counter-vision and counterweight to neoliberal smart city in the spirit of the right to the city movement [169]. Even if there are signs of increased neoliberal tendencies in the Finnish cities-at least partly by design after the electoral success of centrist, populist, and right-wing parties in local and parliamentary elections in 2000s-the discussion above has obvious limitations in making sense of Finnish participatory platformization.

The cities of a welfare society, such as those discussed in this article, even if under economic stress and forced to cut public spending, operate within frameworks which guarantee their residents basic welfare. In such a situation competitiveness policy at national level and entrepreneurial aspirations at local level are justified by the aim to restructure the welfare society and thus to maintain some aspects of the solidaristic redistribution of wealth. From such conditions emanates another kind of people-centered version of the innovation-for-all conception [51]. Moreover, even if the growth agenda is largely written by the growth coalition and a host of intermediary organizations and promotion agencies also in welfare societies, there is clear evidence for a tendency to make the local development processes genuinely inclusive. This is visible in Nordic countries in particular. Institutional embeddedness, compliance with norms, and structures of solidarity seem to tame the urban growth machine and thus ease the dual city or local polarization tendencies. As the tension between the rich and the poor is considerably eased in welfare societies, the trade-off between pro-growth and anti-growth coalitions does not take such a heavy toll on the poor or disadvantaged groups as it does in neoliberal city [167]. This suggests that being able to benefit fully from citizen involvement in producing social coherence, accountability, economic robustness, and self-organization [170] has its societal preconditions, and the welfare society context is in many respects a fruitful ground from which to reap such benefits due to its democratic sentiment and inbuilt solidarity structures. Whether such structures at national and local levels are able to withstand regional harmonization tendencies and global competition is another matter, and appears to be a real challenge to welfare societies in the 21st century.

\section{Conclusions}

Three Finnish cities, Helsinki, Tampere, and Oulu, have started to utilize participatory platforms to foster innovation, which is in line with local strategies and backed up by intercity collaboration (Six City Strategy), the national Innovative Cities (INKA) Program and various programs of the European Union. Profound changes in economic life have increased the need for smart environments, of which a particular form is participatory innovation platform. City has been said to become a platform where people gather to communicate and share ideas and co-create solutions [56]. Another important factor behind the current interest in open and participatory platforms is the participatory turn in public governance and the democratization of innovation. In short, participatory innovation platform is an outcome from a range of intersecting trends, for which Nordic welfare societies seem to provide fruitful soil.

The role of citizen, user, and stakeholder participation in smart environments and platforms in major Finnish cities contributes to urban economic development by enhancing broadly understood productive smartness [32]. Such participation has an inherent instrumental dimension but its rationale goes beyond narrow-minded instrumentalism, as shown by three case-study cities. Helsinki is approaching citizen involvement from a Living Lab point of view. Its key interface is Forum Virium Helsinki. It has created a collaborative and experimental organization culture, which works in the shadow of machine bureaucracy in city government. They form a hyper-text organization, to use Nonaka's terminology [171], which combines the stability and specialization of public hierarchy with the dynamism of cross-functional task-force organization. Tampere has built its approach on stakeholder-involving innovation platforms such as Demola, which have recently been supplemented by Koklaamo and a range of smart city-inspired participatory projects. The latter are learning cases for 
the city government, which has become a better listener for citizens than it was in the post-war decades when local politics was dominated by a coalition known as the Brothers-in-Arms Axis [172]. Oulu relies on business-oriented partnerships and networks, which have a fairly long history. The operations of OULLabs and PATIO are based on open business-minded orientation and professionalism, which involve citizens primarily as customers or users in product and service development projects initiated by local firms. Oulu is characteristically a city that develops and applies user-driven methods in the development of public services [173]. As in all these cases city government facilitates these platforms, they are at least loosely integrated with the official planning system and local development policy, being thus similar to enabler-driven living labs [174-176]. This marks a drastic difference from the self-organized democratization of innovation described by von Hippel [6].

The three cases discussed in this article show that citizens' roles vary from user involvement in product development to the use of citizens' right to take initiatives and bring their concerns to open platforms. The latter aspect is most visible in neighborhood revitalization and the development of city districts, which in most cases also decreases the intensity of business-citizen interaction. Theoretically speaking, participation may vary from nominal to transformative, although in most cases user involvement is instrumental and resident involvement representative $[81,177,178]$. The forms and functions of citizen participation matter, for participatory processes create various forms of citizen involvement, ranging between creativity, passivity and entrenchment, which implies that participation eventually creates different categories of citizen [179]. When participatory innovation platforms become the norm in local development, they gradually reshape the entire city. In the welfare society context democratic culture and institutionalized solidarism provides support to such a transformation, not only in the form of broad civic participation but also at the level of material relations, for asymmetries of micro-level innovation processes and their outcomes are counterweighted by macro structures of solidarity. Such conditions are conducive to the emergence of a smart city that is co-created by its citizens or, as we may call it, the City-as-a-Platform.

Conflicts of Interest: The author declares no conflict of interest.

\section{References}

1. Zysman, J.; Feldman, S.; Murray, J.; Nielsen, N.C.; Kushida, K.E. The new challenge to economic governance: The digital transformation of services. In Innovation in Public Governance; Anttiroiko, A.-V., Bailey, S.J., Valkama, P., Eds.; IOS Press: Amsterdam, The Netherlands, 2011; pp. 30-67.

2. Newman, P.; Thornley, A. Planning World Cities. Globalization and Urban Politics; Palgrave Macmillan: Houndmills, UK, 2005.

3. Anttiroiko, A.-V. New Urban Management: Attracting Value Flows to Branded Hubs; Palgrave Macmillan: Houndmills, UK, 2015.

4. Rondinelli, D.A.; Johnson, J.H., Jr.; Kasarda, J.D. The changing forces of urban economic development: Globalization and city competitiveness in the 21st century. Cityscape 1998, 3, 71-105. [CrossRef]

5. Chesbrough, H.W. The era of open innovation. MIT Sloan Manag. Rev. 2003, 44, 35-41.

6. Von Hippel, E. Democratizing Innovation; MIT Press: Cambridge, MA, USA, 2005.

7. Ramaswamy, V.; Gouillart, F. The Power of Co-Creation: Build It with Them to Boost Growth, Productivity, and Profits; Free Press: New York, NY, USA, 2010.

8. Buur, J.; Matthews, B. Participatory innovation. Int. J. Innov. Manag. 2008, 12, 255-273. [CrossRef]

9. Seltzer, E.; Mahmoudi, D. Citizen participation, open innovation, and crowdsourcing: Challenges and opportunities for planning. J. Plan. Lit. 2013, 28, 3-18. [CrossRef]

10. Bollier, D. The City as Platform: How Digital Networks Are Changing Urban Life and Governance; The Aspen Institute: Washington, DC, USA, 2006.

11. Evans, P.C.; Gawer, A. The Rise of the Platform Enterprise: A Global Survey; The Center for Global Enterprise: New York, NY, USA, 2016.

12. Van Alstyne, M.W.; Parker, G.G.; Choudary, S.P. Pipelines, platforms, and the new rules of strategy. Harvard Bus. Rev. 2016, 94, 54-62. 
13. Krivý, M.; Kaminer, T. Introduction: The participatory turn in urbanism. Footpr. Delft Architect. Theory J. 2013, 13, 1-6.

14. Bergvall-Kåreborn, B.; Ståhlbröst, A. Living lab: An open and citizen-centric approach for innovation. Int. J. Innov. Reg. Dev. 2009, 1, 356-370. [CrossRef]

15. Von Hippel, E. Lead users: A source of novel product concepts. Manag. Sci. 1986, 32, 791-805. [CrossRef]

16. Veeckman, C.; van der Graaf, S. The city as living laboratory: Empowering citizens with the citadel toolkit. Technol. Innov. Manag. Rev. 2005, 5, 6-17.

17. Yin, R.K. Case Study Research: Design and Methods, 4th ed.; Sage: London, UK, 2008.

18. Helsinki City Council. The City of Helsinki Strategy Program 2013-2016; Helsinki City Council: Helsinki, Filand, 24 April 2013. Available online: http://www.hel.fi/static/taske/julkaisut/2013/Strategy_Programme_2013-2016.pdf (accessed on 14 August 2016).

19. The City of Tampere. Tampere: Working together for a Bright Future-Tampere City Strategy 2025. Available online: http://www.tampere.fi/tiedostot/k/P1IFwM6Al/Tampere_City_Strategy.pdf (accessed on 14 August 2016).

20. Oulun Kaupunki. Kaupunkistrategia Oulu 2020 [City Strategy Oulu 2020]; Kaupunginvaltuusto 19.8.2013 §108. Available online: http://www.ouka.fi/c/document_library/get_file?uuid=3cd43780-be77--4bd9--9f09-96d93811cd9a\&groupId=52058 (accessed on 14 August 2016).

21. Culminatum. Innovation Strategy: Helsinki Metropolitan Area; Culminatum-Helsinki Region Centre of Expertise: Espoo, Finland, 2005.

22. TEM. The Six City Strategy-Open and Smart Services. The Cooperation Strategy of the Six Largest Cities in Finland, Approved by the Ministry of Employment and the Economy on 9 June 2014 (TEM/1092/09.02.01/2014), Update 5/2015. Available online: http://www.6aika.fi/wp-content/uploads / 2015/11/6Aika-strategia_päivitys_2015_EN.pdf (accessed on 14 August 2016).

23. Daft, R.L.; Lengel, R.H. Organisational information requirements, media richness and structural design. Manag. Sci. 1986, 32, 554-571. [CrossRef]

24. Nee, V. The new institutionalism in economics and sociology. In The Handbook of Economic Sociology, 2nd ed.; Smelser, N., Swedberg, R., Eds.; Princeton University Press: Princeton, NJ, USA, 2005.

25. Mcloughlin, C. Political Economy Analysis: Topic Guide, 2nd ed.; GSDRC, University of Birmingham: Birmingham, UK, 2014.

26. Caves, R.W. Responding to the information needs of citizens in an open society: The role of smart communities. In eTransformation in Governance: New Directions in Government and Politics; Mälkiä, M., Anttiroiko, A.-V., Savolainen, R., Eds.; Idea Group Publishing: Hershey, PA, USA, 2004; pp. 216-233.

27. Komninos, N. Intelligent Cities. Innovation, Knowledge Systems and Digital Spaces; Spon Press: London, UK; New York, NY, USA, 2002.

28. Komninos, N. Intelligent Cities and Globalisation of Innovation Networks; Routledge: London, UK; New York, NY, USA, 2008.

29. Nam, T.; Pardo, T.A. Conceptualizing smart city with dimensions of technology, people, and institutions. In Proceedings of the 12th Annual International Conference on Digital Government Research: Digital Government Innovation in Challenging Times, College Park, MD, USA, 12-15 June 2011; ACM: New York, NY, USA, 2011; pp. 282-291.

30. Deakin, M.; al Waer, H. From intelligent to smart cities. Intell. Build. Int. 2011, 3, 140-152. [CrossRef]

31. Piro, G.; Cianci, I.; Grieco, L.A.; Boggia, G.; Camarda, P. Information centric services in smart cities. J. Syst. Softw. 2014, 88, 169-188. [CrossRef]

32. Murgante, B.; Borruso, G. Cities and smartness: A critical analysis of opportunities and risks. In Computational Science and Its Applications_ICCSA 2013; Murgante, B., Misra, S., Carlini, M., Torre, C.M., Nguyen, H.-Q., Taniar, D., Apduhan, B.O., Gervasi, O., Eds.; Springer: Berlin, Germany, 2013; pp. 630-642.

33. Anttiroiko, A.-V.; Valkama, P.; Bailey, S.J. Smart cities in the new service economy: Building platforms for smart services. AI Soc. 2013, 29, 323-334. [CrossRef]

34. Angelidou, M. Smart cities: A conjuncture of four forces. Cities 2015, 47, 95-106. [CrossRef]

35. Cohen, B. What Exactly Is a Smart City. Available online: http://www.fastcoexist.com/1680538/whatexactly-is-a-smart-city (accessed on 8 April 2016). 
36. Anthopoulos, L.G.; Vakali, A. Urban planning and smart cities: Interrelations and reciprocities. In The Future Internet: Future Internet Assembly 2012: From Promises to Reality; Alvarez, F., Cleary, F., Daras, P., Domingue, J., Galis, A., Garcia, A., Gavras, A., Karnourskos, S., Krco, S., Li, M.-S., et al., Eds.; Springer: Berlin, Germany, 2012; pp. 178-189.

37. Battarra, R.; Gargiulo, C.; Pappalardo, G.; Boiano, D.A.; Oliva, J.S. Planning in the era of information and communication technologies. Discussing the "label: Smart" in South-European cities with environmental and socio-economic challenges. Cities 2016, 59, 1-7. [CrossRef]

38. Huston, S.; Rahimzad, R.; Parsa, A. 'Smart' sustainable urban regeneration: Institutions, quality and financial innovation. Cities 2015, 48, 66-75. [CrossRef]

39. Angelidou, M. Smart city policies: A spatial approach. Cities 2014, 41, S3-S11. [CrossRef]

40. Papa, R.; Gargiulo, C.; Gladeris, A. Towards and urban plannes' perspective on smart city. TeMA 2013, 1, 5-17.

41. Murgante, B.; Borruso, G. Smart cities in a smart world. In Future City Architecture for Optimal Living; Rassia, S.T., Pardalos, P.M., Eds.; Springer: Basel, Switzerland, 2015; pp. 13-35.

42. Serras, J.; Bosredon, M.; Herranz, R.; Batty, M. Urban Planning and Big Data-Taking LUTi Models to the Next Level? Available online: http://www.nordregio.se/en/Metameny/Nordregio-News/2014/PlanningTools-for-Urban-Sustainability/Reflection/ (accessed on 17 August 2016).

43. Surowiecki, J. The Wisdom of Crowds; Anchor Books: New York, NY, USA, 2005.

44. Howe, J. Crowdsourcing: Why the Power of the Crowd Is Driving the Future of Business; Three Rivers Press: New York, NY, USA, 2009.

45. Anttiroiko, A.-V. Smart cities: Building platforms for innovative local economic restructuring. In Transforming City Governments for Successful Smart Cities; Rodríguez-Bolívar, M.P., Ed.; Springer International Publishing: Cham, Switzerland, 2015; pp. 23-41.

46. Antikainen, M.; Mäkipää, M.; Ahonen, M. Motivating and supporting collaboration in open innovation. Eur. J. Innov. Manag. 2010, 13, 100-119. [CrossRef]

47. Carayannis, E.G.; Campbell, D.F.J. Triple helix, quadruple helix and quintuple helix and how do knowledge, innovation and the environment relate to each other? A proposed framework for a trans-disciplinary analysis of sustainable development and social ecology. Int. J. Soc. Ecol. Sustain. Dev. 2010, 1, 41-69. [CrossRef]

48. McLaren, D.; Agyeman, J. Sharing Cities: A Case for Truly Smart and Sustainable Cities; The MIT Press: Cambridge, MA, USA, 2015.

49. Edwards, F.L. State and local governments prepare for climate change. Public Manag. 2011, 40, 22-26.

50. Hollands, R.G. Will the real smart city please stand up? Intelligent, progressive or entrepreneurial? City 2008, 12, 303-320. [CrossRef]

51. Komninos, N. The Age of Intelligent Cities: Smart Environments and Innovation-for-All Strategies; Routledge: London, UK; New York, NY, USA, 2015.

52. Bifulco, F.; Tregua, M.; Amitrano, C. Living labs for smart innovation: A user-centric approach. In Advances in the Human Side of Service Engineering; Freund, L., Cellary, W., Eds.; CRC Press: Boca Raton, FL, USA, 2014; pp. 828-294.

53. Schaffers, H.; Komninos, N.; Pallot, M.; Aguas, M.; Almirall, E.; Bakici, T.; Barroca, J.; Carter, D.; Corriou, M.; Fernadez, J.; et al. Smart Cities as Innovation Ecosystems Sustained by the Future Internet. Available online: https:/ / www.hal.inria.fr/hal-00769635 (accessed on 25 April 2016).

54. Thornton, B. City-as-a-Platform: Applying Platform Thinking to Cities. Available online: http://www. platformed.info/city-as-a-platform-applying-platform-thinking-to-cities/ (accessed on 23 August 2016).

55. Grech, G. Cities as Platforms. TechCrunch, 7 August 2015. Available online: https://www.techcrunch.com/ 2015/08/07/ cities-as-platforms / (accessed on 23 August 2016).

56. Love, J. Smart Cities Push Public Engagement over Public Policy: IBM Strategist. IT World Canada, 23 September 2015. Available online: http:/ / www.itworldcanada.com/article/what-can-it-leaders-learnfrom-smart-cities-a-lot/377281 (accessed on 23 August 2016).

57. Anttiroiko, A.-V. The role of new technologies in reshaping governance platforms. Int. J. Inf. Commun. Technol. Hum. Dev. 2012, 4, 1-13. [CrossRef]

58. Cooke, P.; de Laurentis, C.; MacNeill, S.; Collinge, C. (Eds.) Platforms of Innovation: Dynamics of New Industrial Knowledge Flows; Edward Elgar: Cheltenham, UK, 2010. 
59. Ghazawneh, A. The role of platforms and platform thinking in open innovation networks. In Proceedings of the 43rd Hawaii International Conference on System Sciences (HICSS), Koloa, Kauai, HI, USA, 5-8 January 2010; IEEE: Washington, DC, USA, 2010; pp. 1-10.

60. Gawer, A.; Cusumano, M.A. How companies become platform leaders. MIT Sloan Manag. Rev. 2008, 49, $28-35$.

61. Janssen, M.; Estevez, E. Lean government and platform-based governance-Doing more with less. Govern. Inf. Q. 2013, 30 (Suppl. S1), S1-S8. [CrossRef]

62. Gawer, A. Towards a General Theory of Technological Platforms. Presented at the Summer Conference 2010 on Opening up Innovation: Strategy, Organization and Technology, Imperial College London Business School, London, UK, 16-18 June 2010; DRUID: Aalborg, Denmark, 2010. Available online: http:/ /www2. druid.dk/conferences/viewpaper.php?id=501981\&cf=43 (accessed on 28 December 2013).

63. Wachhaus, T.A. Governance as a framework to support informatics. Innov. J. 2011, 16, 5.

64. Carstensen, H.V.; Bason, C. Powering collaborative policy innovation: Can innovation labs help? Innov. J. 2012, 17, 4.

65. Cai, Q. Promoting fairness in public policy? Supportive policy for social entrepreneurship. In Fairness in Public Policy: Efficiency, Equity, and Beyond, Proceedings of the Korean Association for Policy Studies KAPS International Conference, Seoul, Korea, 17 June 2011; The Korean Association for Policy Studies: Seoul, Korea, 2011; pp. 301-319.

66. PUMA. Business Improvement District (BID); Progressive Urban Management Associates (P.U.M.A.): Denver, CO, USA, 2010.

67. Grossman, S.A. Public-private partnerships: BID collaboration in Philadelphia. Public Manag. 2010, 39, $38-42$.

68. Koliba, C.; Zia, A.; Lee, B.H.Y. Governance informatics: Managing the performance of inter-organizational governance networks. Innov. J. 2011, 16, 3.

69. Dais, A.; Nikolaidou, M.; Alexopoulou, N.; Anagnostopoulous, D. Introducing a public agency networking platform towards supporting connected governance. In Proceedings of the 7th International Conference, EGOV 2008, Turin, Italy, 31 August-5 September 2008; Wimmer, M.A., Scholl, H.J., Ferro, E., Eds.; Springer: Berlin, Germany, 2008; pp. 375-387.

70. Wang, J.; Wang, Y. Fairness of policy making-In perspective of knowledge utilization. In Fairness in Public Policy: Efficiency, Equity, and Beyond, Proceedings of the Korean Association for Policy Studies KAPS International Conference, Seoul, Korea, 17 June 2011; The Korean Association for Policy Studies: Seoul, Korea, 2011; pp. 635-658.

71. Sefertzi, E. Creativity; Report Produced for the EC Funded Project INNOREGIO: Dissemination of Innovation and Knowledge Management Techniques, January 2000. Available online: http://www.adi.pt/docs/ innoregio_creativity-en.pdf (accessed on 11 October 2013).

72. Mariello, A. The five stages of successful innovation. MIT Sloan Manag. Rev. 2007, 48, 8-9.

73. Preez, N.D.; Louw, L. A framework for managing the innovation process. In Proceedings of the 2008 Portland International Conference on Management of Engineering \& Technology, Portland, OR, USA, 27-31 July 2016; Kocaoglu, D.F., Anderson, T.R., Daim, T.U., Jetter, A., Weber, C.M., Eds.; PICMET, Portland State University: Portland, OR, USA, 2008; pp. 546-558.

74. Şimşit, Z.T.; Vayvay, Ö.; Öztürk, Ö. An outline of innovation management process: Building a framework for managers to implement innovation. Procedia 2014, 150, 690-699. [CrossRef]

75. Buerkler, E. Critical success factors for joint innovation: Experiences from a New Zealand innovation platform. Innov. J. 2013, 18, 8.

76. Foth, M.; Hearn, G. Networked individualism of urban residents: Discovering the communicative ecology in inner-city apartment buildings. Inf. Commun. Soc. 2007, 10, 749-772. [CrossRef]

77. Foth, M.; Choi, J.H.-J.; Satchell, C. Urban Informatics. In Proceedings of the 2011 ACM Conference on Computer Supported Cooperative Work (CSCW), Hangzhou, China, 19-23 March 2011; ACM: New York, NY, USA, 2011; pp. 1-8.

78. Anttiroiko, A.-V. Smart planning: The potential of web 2.0 for enhancing collective intelligence in urban planning. In Emerging Issues, Challenges, and Opportunities in Urban E-Planning; Silva, C.N., Ed.; IGI Global: Hershey, PA, USA, 2015; pp. 1-32.

79. Arnstein, S. A ladder of citizen participation. J. Am. Inst. Plan. 1969, 35, 216-224. [CrossRef] 
80. Kaulio, M.A. Customer, consumer and user involvement in product development: A framework and a review of selected methods. Total Qual. Manag. 1998, 9, 141-149. [CrossRef]

81. White, S.C. Depoliticising development: The uses and abuses of participation. Dev. Pract. 1996, 6, 6-15. [CrossRef]

82. Logan, J.; Molotch, H. Urban Fortunes: The Political Economy of Place; University of California Press: Berkeley, CA, USA; Los Angeles, CA, USA, 1987.

83. Halme, K.; Lindy, I.; Piirainen, K.; Salminen, V.; White, J. Finland as a Knowledge Economy 2.0: Lessons on Policies and Governance; World Bank: Washington, DC, USA, 2014.

84. Katz, B.; Bradley, J. The Metropolitan Revolution: How Cities and Metros Are Fixing Our Broken Politics and Fragile Economy; Brookings Institution Press: Washington, DC, USA, 2013.

85. Schulman, H.; Mäenpää, P. (Eds.) Kaupungin Kuumat Lähteet: Helsingin Metropolialueen Innovaatioympäristöt; Helsingin Kaupungin Tietokeskus: Helsinki, Finland, 2011.

86. Eskelinen, J. Forum virium helsinki-Kaupunkilaiset testaavat palveluja. In Kaupungin Kuumat Lähteet: Helsingin Metropolialueen Innovaatioympäristöt; Schulman, H., Mäenpää, P., Eds.; Helsingin Kaupungin Tietokeskus: Helsinki, Finland, 2011; pp. 34-35.

87. Forum Virium Helsinki. Available online: http://www.forumvirium.fi/en (accessed on 28 December 2013).

88. Forum Virium Helsinki. Avointa Kaupunkia Rakentamassa (Building an Open City); Forum Virium Helsinki: Helsinki, Finland. Available online: https://www.drive.google.com/file/ d/0BxF0q1DY5bSQZy1WQ1pUVFNBeEU/view?pref=2\&pli=1 (accessed on 25 April 2016).

89. Forum Virium Helsinki. Smart City. Available online: http://www.forumvirium.fi/en/project-areas/smart-city (accessed on 8 September 2016).

90. Forum Virium Helsinki. Innovation Communities. Available online: http://www.forumvirium.fi/en/ project-areas/innovation-communities (accessed on 8 September 2016).

91. Helsinki Living Lab. Available online: http:/ / www.helsinkilivinglab.fi/ (accessed on 8 September 2016).

92. Mustonen, V. Smart Kalasatama. PPT-Presentation 13.11.2014. Forum Virium Helsinki. Available online: http://www.en.rakveretarkmaja.ee/uploads/2/0/0/1/20014105/11._v.mustonen.pdf (accessed on 15 August 2016).

93. Von Bruun, S. (Head of City Competitiveness Development Unit, Helsinki, Finland). Personal communication, 11-12 August 2016.

94. Nen, K. (Chief Advisor, Helsinki City Executive Officer, Economic Development, City Competitiveness Unit, Helsinki, Finland). e-Interview, 15 August 2016.

95. Open Helsinki Hack at Home. Available online: http://openhelsinki.hackathome.com/ (accessed on 8 September 2016).

96. BlindSquare. Available online: http:/ / fi.blindsquare.com/ (accessed on 8 September 2016).

97. Ilmastokatu-Climate Street. Available online: http://ilmastokatu.fi/ (accessed on 8 September 2016).

98. Martikka, M. (Project Coordinator, Environment Centre, Helsinki, Finland). Personal communication, 17 August 2016.

99. Partanen, P. Onnistuneen Kehityshankkeen Anatomia. Available online: https://www.forumvirium.fi/ esittely/onnistuneen-kehityshankkeen-anatomia/ (accessed on 23 August 2016).

100. Forum Virium Helsinki. Available online: http://www.forumvirium.fi/en/introduction (accessed on 8 September 2016).

101. Anttiroiko, A.-V. City brands in the mediatised world: Economic profiles of Nordic capitals aggregated from city rankings. Scand. J. Public Adm. 2016, 20, 97-118.

102. Gibson, J.; Robinson, M.; Cain, S. CITIE—City Initiatives for Technology, Innovation and Entrepreneurship; A Resource for City Leadership. Available online: http://www.citie.org/assets/uploads/2015/04/CITIE_ Report_2015.pdf (accessed on 21 August 2016).

103. Tredea. Available online: http:/ /www.tredea.fi/en/ (accessed on 8 September 2016).

104. Kasvio, A.; Anttiroiko, A.-V. (Eds.) e-City: Analysing Efforts to Generate Local Dynamism in the City of Tampere; Tampere University Press: Tampere, Finland, 2005.

105. Inkinen, T. Challenges to digital governance: Perspectives on e-inclusion in Tampere, Finland. In Creative Urban Regions: Harnessing Urban Technologies to Support Knowledge City Initiatives; Yigitcanlar, T., Velibeyoglu, K., Baum, S., Eds.; Information Science Reference: Hershey, PA, USA; New York, NY, USA, 2008; pp. 148-164. 
106. Kautonen, M. Cluster to Platform-Based Innovation Policy. Available online: http://www.innovationcapital. fi/innovation-story/cluster-to-platform-based-innovation-policy (accessed on 25 April 2016).

107. Tredea. Innovaatiotehtaat [Innovation Factories]. Tampereen Kaupunkiseudun Elinkeino- ja Kehitysyhtiö Tredea Oy: Tampere, Finland. Available online: http:/ / www.innovatetampere.fi/innovaatioymparisto/ innovaatiotehtaat/ (accessed on 7 January 2014).

108. Mediapolis. Available online: http://mediapolis.fi/ (accessed on 8 September 2016).

109. City of Tampere. Available online: http://www.tampere.fi/tampereinfo/ajankohtaista/5pz6R2Y6i.html (accessed on 31 December 2013).

110. New Factory. Uusi Tehdas/New Factory. New Factory Ltd., Hermia Group: Tampere, Finland, 2013. Available online: http:/ / www.newfactory.fi/ (accessed on 28 December 2013).

111. Lamminmäki, K.; Salminen, V. Demola: Open Innovation Platform. Available online: https://www. innovationpolicyplatform.org/sites/default/files/rdf_imported_documents/Demola_2014.pdf (accessed on 18 April 2016).

112. Smart City. Demola Network's Accelerator Program. Available online: http:/ /www.smartcityaccelerator.com/ (accessed 8 September 2016).

113. Davey, T.; Deery, M.; Winters, C.; van der Sijde, P.; Kusio, T.; Rodríguez Sedano, S. 30 Good Practice Case Studies in University-Business Cooperation; Part of the DG Education and Culture Study on the Cooperation between Higher Education Institutions and Public and Private Organisations in Europe; Davey, T., Baaken, T., Deery, M., Galan-Muros, V., Eds.; European Commission: Brussels, Belgium. Available online: http:/ /www. ec.europa.eu/education/higher-education/doc/studies/munstercase_en.pdf (accessed on 28 December 2013).

114. Kilamo, T.; Hammouda, I.; Kairamo, V.; Räsänen, P.; Saarinen, J.P. Applying open source practices and principles in open innovation: The case of the demola platform. In Open Source Systems: Grounding Research; Hissam, S.A., Russo, B., de Mendonça Neto, M.G., Kon, F., Eds.; Springer: Berlin, Germany, 2011; pp. 307-311.

115. Bessonova, A. How Startups Are Built in Tampere: Case of Demola. ArcticStartup, 1 September 2011. Available online: http:/ /www.arcticstartup.com/2011/09/01/how-startups-are-built-in-tampere-case-ofdemola (accessed on 25 January 2014).

116. Salomaa, A. Innovation in Higher Education: Case Demola. Co-Creation Platform for Talented Students, Companies and Universities. Available online: http://www.ec.europa.eu/education/events/2013/ 20131118/salomaa_en.pdf (accessed on 25 January 2014).

117. Demola. Available online: http://tampere.demola.fi/ (accessed on 8 September 2016).

118. Välimäki, P. (Development Manager, INKA Program, Tampere, Finland). e-Interview, 10 August 2016.

119. Koklaamo (Tampere, Finland). Työpaja 4.8.2016 [Workshop 4.8.2016]. Unpublished Work, 2016.

120. Leskinen, A. (Development Manager of Local Democracy, Tampere, Finland). e-Interview, 10 August 2016.

121. Mustikkamäki, N. (Project Manager, Open Innovation Platforms (Oma Tesoma Project), Tampere, Finland). Informal personal interview in Tampere on 27 August 2016, and personal communication, 10 August 2016.

122. Nokkonen, O. (Project Planner, 6Aika Open Participation and Customership, Tampere, Finland). Personal communication, 17 August 2016.

123. Myllymäki, J. (Development Manager, Tampere Region Economic Development Agency Tredea, Tampere, Finland). e-Interview, 11 August 2016.

124. EU Gugle. Tampere. Available online: http://eu-gugle.eu/pilot-cities/tampere/ (accessed 8 September 2016).

125. Väliaikainen Hiedanranta. Available online: http://valiaikainenhiedanranta.fi/ (accessed 8 September 2016).

126. Jokinen, J. (Development Manager, Smart City, Tampere Region Economic Development Agency Tredea, Tampere, Finland). e-Interview, 15 August 2016.

127. Technopolis. Available online: http://www.technopolis.fi/en/ (accessed on 8 September 2016).

128. Oinas-Kukkonen, H.; Similä, J.; Kerola, P.; Pulli, P.; Saukkonen, S. Development in the growth base of the 'Oulu Phenomenon': The role of systems/software methodologies. In IFIP International Federation for Information Processing, Proceedings of the IFIP WG9.7 First Working Conference on the History of Nordic Computing (HiNC1), Trondheim, Norway, 16-18 June 2003; Bubenko, J., Impagliazzo, J., Solvberg, A., Eds.; Springer: New York, NY, USA, 2005; Volume 174, pp. 425-447.

129. Vincze, Z.; Teräs, J. Mechanisms of innovation-based cluster transformation. In Innovation Drivers and Regional Innovation Strategies; Parilli, M.D., Fitjar, R.D., Rodriguez-Pose, A., Eds.; Routledge: New York, NY, USA, 2016; pp. 85-104. 
130. Ala-Rämi, K. Social networking and knowledge transfer in collaborative product development. In Creative Urban Regions: Harnessing Urban Technologies to Support Knowledge City Initiatives; Yigitcanlar, T., Velibeyoglu, K., Baum, S., Eds.; IGI Global, Information Science Reference: Hershey, PA, USA, 2008; pp. 65-79.

131. OuluHealth Labs. Available online: http://ouluhealth.fi/labs/ (accessed 8 September 2016).

132. Mapgets. Available online: https://mapgets.com (accessed 8 September 2016).

133. BusinessKitchen. Available online: http://www.businesskitchen.fi/ (accessed 8 September 2016).

134. Oulun Yritystakomo Oy. Available online: http://www.yritystakomo.fi (accessed 8 September 2016).

135. Demola Oulu. Available online: http:/ / oulu.demola.net (accessed 8 September 2016).

136. YLE. PanOulu Pitää Pintansa Mobiilidatan Puristuksessa [PanOulu Hangs on in Spite of the Coming of Mobile Data]. Available online: http://www.yle.fi/uutiset/panoulu_pitaa_pintansa_mobiilidatan_ puristuksessa/7056167 (accessed on 26 April 2016).

137. Anttiroiko, A.-V. Towards ubiquitous government: The case of Finland. e-Serv. J. 2005, 4, 65-99. [CrossRef]

138. Intelligent Community Forum. Top7 Intelligent Community of 2013. Available online: http://www. intelligentcommunity.org/index.php?src=news\&refno=768\&category=Community (accessed on 27 April 2016).

139. Huhmo, H. (Project Manager, 6Aika Open Innovation Platforms, BusinessOulu, Oulu, Finland). e-Interview, 16 August 2016.

140. OULLabs. Available online: http:/ /www.oullabs.fi/ (accessed 8 September 2016).

141. Haukipuro, L.; Väinämö, S.; Arhippainen, L. Living lab as one-stop-shop in the development of public services. Interdiscip. Stud. J. 2014, 3, 157-162.

142. PATIO. Available online: http://www.patiolla.fi/en/ (accessed 8 September 2016).

143. Väinämö, S. (Director of OULLabs, Center for Internet Excellence, University of Oulu, Oulu, Finland). e-Interview, 17 August 2016.

144. Laizane, S.; Haukipuro, L.K. Preliminary experiences with the online forum PATIO in a multi-contextual living lab environment. In Proceedings of the ISM 2012 Workshop on Innovation through Social Media, Oslo, Norway, 3 December 2012; Følstad, A., Ståhlbröst, A., Ebbesson, E., Svensson, J., Eds.; Academika Forlag: Trondheim, Norway, 2012; pp. 24-31.

145. Mäkinen, P. (Chief Audit Executive (former Development Manager), Oulu, Finland). Informal personal interview in Tampere, 5 August 2016.

146. Kallioniemi, L. (City Planning Architect, Oulu, Finland). Personal communication, 17 August 2016.

147. Bingham, L.B.; Nabatchi, T.; O'Leary, R. The new governance: Practices and processes for stakeholder and citizen participation in the work of government. Public Adm. Rev. 2005, 65, 547-558. [CrossRef]

148. Irvin, R.A.; Stansbury, J. Citizen participation in decision making: Is it worth the effort? Public Adm. Rev. 2004, 64, 55-65. [CrossRef]

149. Lawson, L.; Kearns, A. Rethinking the purpose of community empowerment in neighbourhood regeneration: The need for policy clarity. Local Econ. 2014, 29, 65-81. [CrossRef]

150. Peris, S.J. Urban regeneration's poisoned chalice: Is there an impasse in (community) participation-based policy? Urban Stud. 2003, 40, 581-601.

151. Nam, T. Suggesting frameworks of citizen-sourcing via Government 2.0. Gov. Inf. Q. 2012, 29, 12-20. [CrossRef]

152. Brabham, D.C. Crowdsourcing the public participation process for planning projects. Plan. Theory 2009, 8 , 242-262. [CrossRef]

153. Kuokkanen, K. Developing Participation through Projects? A Case Study from the Helsinki Metropolitan Area; Faculty of Social Sciences, University of Helsinki: Helsinki, Finland, 2016. Available online: https://www. helda.helsinki.fi/bitstream/handle/10138/160808/DEVELOPI.pdf?sequence=1 (accessed on 15 April 2016).

154. Hollands, R.G. Critical interventions into the corporate smart city. Camb. J. Reg. Econ. Soc. 2015, 8, 61-77. [CrossRef]

155. Mustonen, P. How Helsinki Became a Trailblazer in Urban Culture: Chronicling Two Decades of Change. Kvartti 4/2014. Available online: http://www.kvartti.fi/en/articles/how-helsinki-became-trailblazerurban-culture (accessed on 22 August 2016).

156. Greer, J.L. The political economy of the local state. Political Soc. 1987, 15, 513-538. [CrossRef]

157. Harvey, D. From managerialism to entrepreneurialism: The transformation in urban governance in late capitalism. Geogr. Ann. Ser. B 1989, 71, 3-17. [CrossRef]

158. Hall, T.; Hubbard, P. The entrepreneurial city: New urban politics, new urban geographies? Prog. Hum. Geogr. 1996, 20, 153-174. [CrossRef] 
159. Hackworth, J. The Neoliberal City: Governance, Ideology and Development in American Urbanism; Cornell University Press: Ithaca, NY, USA, 2007.

160. Weaver, T.P.R. Blazing the Neoliberal Trail: Urban Political Development in the United States and the United Kingdom; University of Pennsylvania Press: Philadelphia, PA, USA, 2016.

161. Turok, I. Property-led urban regeneration: Panacea or placebo? Environ. Plan. A 1992, 24, 361-379. [CrossRef]

162. Greenwood, D.T.; Holt, R.P.F. Growth, inequality and negative trickle down. J. Econ. Issues 2010, 44, 403-410. [CrossRef]

163. Thomas, V.; Wang, D.; Mullagh, L.; Dunn, N. Where's Wally? In search of citizen perspectives on the smart city. Sustainability 2016, 8, 207. [CrossRef]

164. Stone, C. Regime Politics: Governing Atlanta, 1946-1988; University Press of Kansas: Lawrence, KS, USA, 1989.

165. Long, J. Constructing the narrative of the sustainability fix: Sustainability, social justice and representation in Austin, TX. Urban Stud. 2014, 53, 149-172. [CrossRef]

166. Yanarella, E.J.; Lancaster, R.W. Getting from Here to There? Power, Politics and Urban Sustainability in North America; BrownWalker Press: Boca Raton, FL, USA, 2016.

167. Tretter, E. Sustainability and neoliberal urban development: The environment, crime and the remaking of Austin's downtown. Urban Stud. 2013, 50, 2222-2237. [CrossRef]

168. Stimmel, C.L. Building Smart Cities: Analytics, ICT, and Design Thinking; CRC Press: Boca Raton, FL, USA, 2016.

169. Harvey, D. Rebel Cities: From the Right to the City to the Urban Revolution; Verso: London, UK; New York, NY, USA, 2012.

170. Boonstra, B.; Boelens, L. Self-organization in urban development: Towards a new perspective on spatial planning. Urban Res. Pract. 2011, 4, 99-122. [CrossRef]

171. Nonaka, I. A dynamic theory of organizational knowledge creation. Organ. Sci. 1994, 5, 14-37. [CrossRef]

172. Laine, M.; Peltonen, L. Regime stability and restructuration: From industrial to informational city. In $e$-City: Analysing Efforts to Generate Local Dynamism in the City of Tampere; Kasvio, A., Anttiroiko, A.-V., Eds.; Tampere University Press: Tampere, Finland, 2005; pp. 345-388.

173. Haukipuro, L.; Väinämö, S.; Arhippainen, L. Citizen and employee involvement in public service development through user-driven methods. In Proceedings of the 2014 International Conference on Engineering, Technology and Innovation (ICE), Bergamo, Italy, 23-25 June 2016.

174. Juujärvi, S.; Pesso, K. Actor roles in an urban living lab: What can we learn from Suurpelto, Finland? Technol. Innov. Manag. Rev. 2013, 3, 22-27.

175. Leminen, S.; Westerlund, M.; Nyström, A.-G. Living labs as open-innovation networks. Technol. Innov. Manag. Rev. 2012, 2, 6-11.

176. Walravens, N. The city as a platform. In Proceedings of the 2011 15th International Conference on Intelligence in Next Generation Networks (ICIN), Berlin, Germany, 4-7 October 2011; pp. 283-288.

177. Leminen, S.; Westerlund, M.; Nyström, A.-G. On becoming creative consumers-User roles in living labs networks. Int. J. Technol. Mark. 2014, 9, 33-52. [CrossRef]

178. Arnkil, R.; Järvensivu, A.; Koski, P.; Piirainen, T. Exploring Quadruple Helix: Outlining User-Oriented Innovation Models; Working Papers 85/2010; Work Research Centre, University of Tampere: Tampere, Finland, 2010.

179. Turnhout, E.; van Bommel, S.; Aarts, N. How participation creates citizens: Participatory governance as performative practice. Ecol. Soc. 2010, 15, 26.

(C) 2016 by the author; licensee MDPI, Basel, Switzerland. This article is an open access article distributed under the terms and conditions of the Creative Commons Attribution (CC-BY) license (http://creativecommons.org/licenses/by/4.0/). 